Immune mediators in idiopathic uveitis

\title{
IMMMUNE MEDIATORS IN IDIOPATHIC UVEITIS
}

\author{
Immmune mediators in idiopathic uveitis
}

Marie-Hélène Errera ${ }^{1,2,3}$, Ana Pratas, ${ }^{1}$ Sylvain Fisson, ${ }^{6}$ Thomas Manicom, ${ }^{1,2}$ Marouane Boubaya, ${ }^{4}$ Neila Sedira, ${ }^{1}$ Emmanuel Héron, ${ }^{1}$ Lilia Merabet, ${ }^{1}$ Alfred Kobal, ${ }^{1}$ Vincent Levy, ${ }^{4}$ Jean-Michel Warnet, ${ }^{5}$ Christine Chaumeil, ${ }^{1}$ Françoise Brignole-Baudouin, ${ }^{1,5}$ José-Alain Sahel, ${ }^{1,2,3}$ Pablo Goldschmidt, ${ }^{1}$ Bahram Bodaghi, ${ }^{2,7}$ Coralie Bloch-Queyrat, ${ }^{4}$

${ }^{1}$ Laboratory, Departments of Ophthalmology and Internal Medicine at Quinze-Vingts National Eye Hospital and DHU Sight Restore, Paris, France.

${ }^{2}$ Sorbonne Universités, UPMC Univ Paris 06, France.

${ }^{3}$ Department of Ophthalmology, UPMC Eye Center, University of Pittsburgh School of Medicine, Pennsylvania, USA

${ }^{4}$ Université Paris 13, Sorbonne Paris cité, INSERM U1163/CNRS ERL 8254, AP-HP, Hôpital Avicenne, URC-CRC GHPSS, Bobigny, France

${ }^{5}$ Faculty Pharmacy, Sorbonne Universities, Paris 05, France

${ }^{6}$ Généthon, Inserm UMR_S951, Univ Evry, Université Paris-Saclay, EPHE, Evry, France

${ }^{7}$ Pitié-Salpêtrière hospital, and DHU Sight Restore, Paris, France. Sorbonne University, UPMC Univ Paris 06, France.

Address for correspondance : Marie-Hélène Errera, UPMC Eye Center, University of Pittsburgh School of Medicine, Pittsburgh, Pennsylvania, USA

Tel +14126268825

erreram@upmc.edu 
Immune mediators in idiopathic uveitis

Financial Support : Institut de la Vision et CIC 1423, France, Paris, Association Inflam'œil Conflict of interest : None

\begin{abstract}
To investigate which cytokines, chemokines and growth factors are involved in the immunopathogenesis of idiopathic uveitis, and whether cytokine profiles are associated with. Serum and aqueous humor (AH) samples of 75 patients with idiopathic uveitis were analyzed by multiplex immunoassay. Infectious controls consisted of 16 patients with ocular toxoplasmosis all confirmed by intraocular fluid analyses. Noninfectious controls consisted of 7 patients with Behçet disease related uveitis and 15 patients with sarcoidosis related uveitis. The control group consisted of $\mathrm{AH}$ and serum samples from 47 noninflammatory control patients with age-related cataract. In each sample, 27 immune mediators \pm IL-21 and IL-23 were measured. In idiopathic uveitis, 13 of the 29 mediators, including most proinflammatory and vascular mediators such as IL-6, IL-8, IL-12, G-CSF, GM-CSF, MCP-1, IP-10, TNF- $\alpha$ and VEGF, were significantly elevated in the aqueous humor when compared to all controls. Moreover, IL-17, IP-10, and IL-21, were significantly elevated in the serum when compared to all controls. We clustered 4 subgroups of idiopathic uveitis using a statistical analysis of hierarchical unsupervised classification, characterized by the order of magnitude of concentrations of intraocular cytokines. The pathogenesis of idiopathic uveitis is characterized by the presence of predominantly proinflammatory cytokines and chemokines and vascular endothelial growth factor with high expression levels as compared to other causes of uveitis. There are indications for obvious Th-1/ IL21-Th17 pathways but also IL9-Th9 and increased IFN- $\gamma$-inducing cytokine (IL12) and IFN- $\gamma$-inducible CXC chemokine (IP-10). The combined data suggest that immune mediator expression is different among idiopathic uveitis. This study suggests various clusters among the idiopathic uveitis group rather than one specific uveitis entity.
\end{abstract}

Key-words: cytokines, chemokines, idiopathic uveitis, intermediate uveitis, posterior uveitis, panuveitis 
Immune mediators in idiopathic uveitis

\section{INTRODUCTION}

Uveitis refers to a variety of clinical presentations with different phenotypes. Idiopathic

60 from unknown etiology (or idiopathic uveitis) is reported for $35 \%$ of cases, and $10 \%$ leads to

61 blindness in developed countries. Some idiopathic uveitis could be autoimmune or infectious uveitis undiagnosed. There is still no gold standard for the diagnosis of these ocular inflammatory diseases. The idiopathic character is a diagnosis of exclusion when the clinical, radiological and biological work-up are noncontributive and the ophthalmological examination is nonpathognomonic for a particular entity. However, the question remains: what is the initial cause of those inflammatory process in the eye? Moreover, familial cases of intermediate idiopathic uveitis and other autoimmune diseases suggest that genetic variants and/or a single environmental agent are probably the cause of auto-immune diseases. Indeed, the hypothesis of a susceptibility to uveitis stemming from genetic determinants, as seen in other immunological diseases, has been initially suggested by their mode of hereditary transmission in certain families. One hypothesis would that an infectious agent (virus or bacteria) would activate systematically the autoreactive $\mathrm{T}$ lymphocytes in patients genetically predisposed. It is therefore possible to consider a microbial agent as an initiating or potentiating factor. We know that in certain cases, viral infections even eradicated, may have introduced immune responses, propagate these responses by using molecular mimics

One means by which microbial agents can play a role is by their adjuvant effect, for example, in shifting the balance of the immune responses which are normally controlled by the inhibitory regulator mechanisms, toward mechanisms that predispose patients to developing one of these illnesses.

Moreover, we know very little about the immune mechanisms involved in uveitis and in particular in the idiopathic ones.

82 Research on the subject is limited due to the difficulty of obtaining histological samples from inflamed eyes in humans. Animal models permit the exploration of these mechanisms in vivo but are rarely relevant. Studies in mice show that effector cells Th1 and Th17 can independently induce tissue changes in uveitis models [1]. The eye is relatively protected from the immune system by the blood retinal barrier, by the immune inhibitor environment and active tolerance mechanisms involving CD4+ regulatory $\mathrm{T}$ lymphocytes (regulatory $\mathrm{T}$ cells or Tregs) that could 
Immune mediators in idiopathic uveitis

88 influence the susceptibility to developing uveitis which is the case in other immunological

89 diseases including multiple sclerosis (MS) or rheumatoid arthritis [2], [3]. The resident retinal

90 cells such as the Müller glia cells and those of the pigment epithelium contribute to this micro

91 environment by the production of cytokines. The level of these cytokines determines their

92 diverse susceptibility to induce uveitis [4], [5].

93 The study of the immune mechanisms in idiopathic uveitis could answer this question.

94 By means of collecting aqueous humor (AH) samples we have direct access to the intra-ocular

95 compartment, and an assay of the mediators of inflammation enabling the analysis of this

96 inflammation at the site of activity.

97 The aim of this study was to investigate which cytokine, chemokines and growth factors are

98 involved in the immunopathogenesis of idiopathic uveitis and whether specific cytokines

99 profiles are associated with clinical manifestations. To this end, cytokines, chemokines and

100 growth factors profiles in the $\mathrm{AH}$ and serum were determined by multiplex immunoassay

101 (Luminex®) technology. 
Immune mediators in idiopathic uveitis

\section{Ethics statement and subjects}

This study was conducted in the Quinze-Vingts National Ophthalmologic Eye Center,

106 Paris, France between January 2014 and May 2016. The French institutional review

107 boards/Ethics Committee approval was obtained (registration number 13934 at CPP-Ile-de-

108 France, St-Antoine Hospital, Paris, France). Written informed consents to participate to the

109 study were obtained from all participants with none of the patients objecting to the use of the

110 remnants of their samples for further research. This study was conducted according to the tenets

111 of the Declaration of Helsinki.

Results of 27 cytokines, chimiokines and growth factors from paired AH and sera $(n=$

11369 and 63, respectively) from 75 patients diagnosed with idiopathic uveitis were compared to

114 mediator profiles detected in paired $\mathrm{AH}$ and serum samples of 47 control patients from patients

115 with age-related cataract ( $n=47$ and $n=36$, respectively). Results of both cytokines, IL-21 and

116 IL-23, from paired AH and sera ( $n=68$ and $n=58$, respectively) from the patients with idiopathic

117 uveitis were compared to the ones from controls age-related cataract ( $n=16$ and 7, respectively).

118 Additional information on the patient groups were presented in Table 1.

\begin{tabular}{|c|c|c|c|c|}
\hline & \multicolumn{4}{|c|}{$\begin{array}{l}\text { Biological media } \\
\text { AH }\end{array}$} \\
\hline & $\begin{array}{l}\text { total number } \\
\text { of samples }(n)\end{array}$ & number analyzed $(n)$ & $\begin{array}{l}\text { total number } \\
\text { of samples } \\
(n)\end{array}$ & $\begin{array}{l}\text { number analyzed } \\
(n)\end{array}$ \\
\hline \multicolumn{5}{|l|}{ Patients groups } \\
\hline $\begin{array}{l}\text { Noninflammatory } \\
\text { controls (age-related } \\
\text { cataract) }\end{array}$ & 36 & $\begin{array}{l}\text { - } 27 \text { cytokines (36) } \\
\text { - IL-21 \& IL-23 (7) }\end{array}$ & 47 & $\begin{array}{l}\text { - } 27 \text { cytokines (47) } \\
-\quad \text { IL-21 \& IL-23 } \\
(16)\end{array}$ \\
\hline $\begin{array}{l}\text { uveitis related to } \\
\text { Behçet disease }\end{array}$ & 5 & $\begin{array}{l}\text { - } 27 \text { cytokines (5) } \\
\text { - IL-21 \& IL-23 (1) }\end{array}$ & 7 & $\begin{array}{l}\text { - } 27 \text { cytokines (7) } \\
\text { - IL-21 \& IL-23 (6) }\end{array}$ \\
\hline ocular sarcoidosis & 15 & $\begin{array}{l}\text { - } 27 \text { cytokines (15) } \\
\text { - IL-21 \& IL-23 (3) }\end{array}$ & 12 & $\begin{array}{l}\text { - } 27 \text { cytokines (12) } \\
-\quad \text { IL-21 \& IL-23 } \\
\text { (14) }\end{array}$ \\
\hline ocular toxoplasmosis & 16 & $\begin{array}{l}\text { - } 27 \text { cytokines (11) } \\
\text { - IL-21 \& IL-23 (3) }\end{array}$ & 16 & $\begin{array}{l}\text { - } 27 \text { cytokines (16) } \\
-\quad \text { IL-21 \& IL-23 } \\
\text { (14) }\end{array}$ \\
\hline idiopathic uveitis & 75 & $\begin{array}{l}\text { - } 27 \text { cytokines (69) } \\
\text { - IL-21 \& IL-23 (58) }\end{array}$ & 75 & $\begin{array}{l}\text { - } 27 \text { cytokines (63) } \\
-\quad \text { IL-21 \& IL-23 } \\
\text { (68) }\end{array}$ \\
\hline
\end{tabular}


Immune mediators in idiopathic uveitis

Table 1: Total number of paired $\mathrm{AH}$ and serum samples analyzed.

121

122

125

126

127

128

130

\section{AH : aqueous humor}

Paired sera and $\mathrm{AH}$ samples obtained from patients with uveitis related to toxoplasmosis (TU) $(n=16)$, uveitis related to Behçet disease $(n=7)$ and ocular sarcoidosis $(\mathrm{N}=15)$ served as disease controls. The same exclusion criteria than for the uveitis group applied to the healthy donors and they did not have any clinical symptoms of uveitis. Exclusion criteria was glaucomatous and diabetes because elevated IL-6 and IL-8 levels were also reported in glaucomatous aqueous with elevated IOP and diabetes [6], [7].

Patients were identified and referred for enrolment by ophthalmologists after careful examination and evaluation by internal medicine specialists. In this study, paired $\mathrm{AH}$ and serum samples of 75 patients with idiopathic uveitis were included. The criteria for idiopathic (or unknow etiologies) were investigations oriented by the anatomic characteristics of uveitis: negative serologic screening for syphilis, normal serum angiotensin-converting enzyme, and interferon-gamma release, normal chest computed tomography, normal cerebral magnetic resonance imaging and normal anterior chamber tap with interleukin-10 analysis (when intermediate or posterior uveitis in patients $>40$ years-old) [8] and/or cytology, Herpes viridea (HSV, VZV, CPV) PCR and/or Goldmann coefficient (when severe infectious uveitis suspected), after medical history of the patient and physical examination performed and excluding any past history of systemic inflammation, auto-immune disease, concomitant antiinflammatory treatment, immunosuppressed state or systemic antibiotics or immunomodulatory therapy within 4 weeks before inclusion. The classification of uveitis used was the anatomical classification (the International Uveitis Study Group (IUSG) [9].

-The 47 patients who underwent cataract extraction ( 27 women and 20 men; median age 71 years [30-100 years]) and served as a control group had no history of uveitis. Sera and AH samples were collected prior to cataract extraction. The baseline level of cytokines/ chemokines in $\mathrm{AH}$ was determined using samples from the control group.

-For control group consistent with TU and serving as infectious disease controls, the diagnosis of TU was confirmed by real-time PCR detection of Toxoplasma gondii DNA or a Goldmann-Witmer test to prove intraocular specific antibody synthesis. Patients who were 
150 immunocompromised, suffered from other ocular infections, or receiving local or systemic anti-

151 Toxoplasma treatment for active uveitis, were excluded.

152

153

-For disease control group consistent with ocular sarcoidosis, the patients included fulfilled the standardized nomenclature based on the International Workshop on Ocular Sarcoidosis (IWOS) as definite presumed, probable and possible ocular sarcoidosis [10].

\section{Biological analysis}

Paired samples of AH and serum were obtained from each subject at the time of clinical diagnosis for laboratory analysis. AH samples $(100-150 \mu \mathrm{L})$ were collected through anterior chamber paracentesis and stored, along with serum samples, at $-80^{\circ} \mathrm{C}$ until analysis.

In each sample, 27 immune mediators were analyzed: 4 anti-inflammatory cytokines (interleukin IL-1 receptor antagonist [IL-1R $\alpha$ ], [IL]-4, IL5, IL-10, and IL-13); 12 proinflammatory mediators (cytokines IL-1 $\beta$, IL-2, IL-6, IL-12p70, IL-17, interferon- $\gamma$ [IFN$\gamma$ ], tumor necrosis factor- $\alpha$ [TNF- $\alpha$ ], and chemokines IL-8 [CXCL8], interferon-inducible 10kDa protein [IP-10; CXCL10], monocyte chemotactic protein-1 [MCP-1; CCL2], macrophage inflammatory protein-1 $\alpha$ [MIP1 $\alpha$; CCL3]; and $-1 \beta$ [MIP-1 $\beta$; CCL4); 3 additional mediators (cytokines IL-15 and macrophage migration inhibitory factor [MIF], and chemokines RANTES [regulated on activation, normal T-cell expressed and secreted; CCL5] and Eotaxin [CCL11]); granulocyte-macrophage colony-stimulating factor [G-CSF], granulocyte-macrophage colonystimulating factor [GM-CSF], 4 growth factors [hematopoietic growth factor [IL-7], Fibroblast growth factor [FGF Basic], Platelet-derived growth factor [PDGF-BB], vascular endothelial growth factor [VEGF]].

$\mathrm{AH}$ and serum samples were analyzed by multiplex immunoassay (Luminex ${ }^{\circledR}$ ). The assay plate layout consisted in a standard series in duplicate (1 to $32000 \mathrm{pg} / \mathrm{mL}$ ), four blankwells and $10 \mu \mathrm{L}$ duplicates of $\mathrm{AH}$ samples, diluted to $50 \mu \mathrm{L}$ with BioPlex Human serum diluent. Quantitative determination was performed in culture supernatant using an Invitrogen Human Cytokine 27-Plex Panel. The 27 plex was enriched with and one separate Invitrogen Human Cytokine 2-Plex Panel for IL-21, IL-23 and in accordance with the manufacturer's protocol (BioRad®).

\section{Statistical analysis}



tests were performed to compare continuous variables, as appropriate. $\mathrm{P}$ values less than 0.05 were considered significant. The statistical analyses were performed using GraphPad Prism version 8.0.1, Graph Pad Software, Inc, San Diego, CA.

The comparaison of dosage of different cytokines, chemokines and growth factors between idiopathic uveitis and various controls was done using a non parametric test of Mann-Whitney.

185 The representation of cytokine distributions (boxplots) was performed according to pathology groups, with comparisons between controls vs other pathologies (Bechet, sarcoïdoses and toxoplasmosis) with a correction of P-values with the method of Bonferroni (to avoid alpha risk inflation due to multiple comparisons).

The classification of cytokines in idiopathic uveitis was done by selecting only the uveitis significantly different from those of the controls. The method used is the hierarchical unsupervised classification after focusing and reducing the data (subtract the mean and divide by standard deviation) in order to report the cytokines in the same unit (around 0 ).

A distribution of clinical data according to the groups identified in the classification was presented. No comparison tests were conducted because of the exploratory nature of the analysis as well as the low number per group.

\section{Results chemokines, cytokines and growth factors in the serum:}

Patients with idiopathic uveitis exhibited higher levels of IP-10, IL-17, and IL-21 than serum samples of cataract patients.

200 Specifically, median levels of chemokines and cytokines IP-10, IL-17, and IL-21 were 201 significantly elevated in the serum of patients with idiopathic uveitis as compared with 202 nonflammatory controls : $671 \mathrm{pg} / \mathrm{mL}$ [157-3063] vs $526 \mathrm{pg} / \mathrm{mL}$, for IP-10; $173 \mathrm{pg} / \mathrm{mL}$ [39$203500]$ vs $49 \mathrm{pg} / \mathrm{mL}$ for IL-17 and $28 \mathrm{pg} / \mathrm{mL}$ [0-382] vs $0 \mathrm{pg} / \mathrm{mL}$ for IL-21 ( $\mathrm{p}=0.0087, \mathrm{p}<0,0001$, $p=0.0035$, respectively) (fig. 1). Median levels of IL-23 was decreased in the serum of patients with idiopathic uveitis as compared with noninflammatory controls: $11 \mathrm{pg} / \mathrm{mL}$ [0-187] vs 6 $\mathrm{mg} / \mathrm{mL}[0-22](\mathrm{p}<0.0001)$.

207 However, median levels of the following mediators in serum in patients with idiopathic uveitis 208 were not significantly different as compared with controls: proinflammatory cytokines and 
Immune mediators in idiopathic uveitis

chemokines IL-1 $\beta$, IL-6, IFN- $\gamma$, TNF- $\alpha$, MCP-1, G-CSF, MIP-1 $\alpha$, and MIP-1 $\beta$; antiinflammatory cytokines IL-10, IL1-R $\alpha$, and the angiogenic growth factor VEGF.

Some patients with idiopathic uveitis had increased levels of chemokines, cytokines and growth factors as compared with the cut-off defined in control patients (mean +3 standard deviation): IL-23 in 6 patients, IL-7 in 7 patients, IL-1 $\beta$ and PDGF-BB in 5 patients; IL- 6 in 4 patients ; IL$1 \mathrm{R} \alpha$ in 3 patients; IL-2, IL-4, IL-10, IL-12, GM-CSF, VEGF in 2 patients and IL-15, G-CSF, IFN- $\gamma$, MIP- $1 \alpha$, MIP-1 $\beta$, RANTES, TNF- $\alpha$ in one patient ; nonetheless, differences between median levels found in the samples from patients with idiopathic uveitis as compared with the controls' were not significant for those mediators (fig 2).

\section{Results chemokines, cytokines and growth factors in the AH (Table 2 and Figures 3a, 3b,} 3c,3e):

Patients with uveitis exhibited higher levels of IL-5, IL-6, IL-8, IL-12, IP-10, MCP-1, G-CSF, GM-CSF, MIP-1 $\alpha$, MIP-1 $\beta$, TNF- $\alpha$ and VEGF than intraocular fluid samples of cataract patients, whilst IL-4 was lower.

Specifically, median levels of chemokines, cytokines, and growth factors were significantly increased in the $\mathrm{AH}$ of idiopathic uveitis as compared with noninflammatory controls : IL-1R $\alpha$ was $50.92 \mathrm{pg} / \mathrm{mL}$ [0-126.9] vs $0.83 \mathrm{pg} / \mathrm{mL}$, IL-5 was $0 \mathrm{pg} / \mathrm{mL}$ [0-5.52] vs $0 \mathrm{pg} / \mathrm{mL}$; IL-6 was $81.73 \mathrm{pg} / \mathrm{mL}$ [8.82-511.2] vs $6.64 \mathrm{pg} / \mathrm{mL}$, IL-8 was $22.23 \mathrm{pg} / \mathrm{mL}$ [2.12-87.86] vs 2.76, l'IL-9 was $2.85 \mathrm{pg} / \mathrm{mL}$ [0-8.8] vs $0 \mathrm{pg} / \mathrm{mL}$, IL-12 was $11.13 \mathrm{pg} / \mathrm{mL}$ [5.67-20,49] vs 3.30; Eotaxine was $6.29 \mathrm{pg} / \mathrm{mL}$ [0-30.61] vs $0 \mathrm{pg} / \mathrm{mL}$; IP-10 was $4442 \mathrm{pg} / \mathrm{mL}$ [462.8-17790] vs 284.74; GCSF was $9.98 \mathrm{pg} / \mathrm{mL}$ [1.47-113.3] vs $0.64 \mathrm{pg} / \mathrm{mL}$, MCP-1 was $125.2 \mathrm{pg} / \mathrm{mL}$ [46.24-315.8] vs 59; GM-CSF was $3.5 \mathrm{pg} / \mathrm{mL}$ [0-100.40] vs $0 \mathrm{pg} / \mathrm{mL}$; MIP-1 $\alpha$ was $1.21 \mathrm{pg} / \mathrm{mL}$ [0-2.66] vs 0 $\mathrm{pg} / \mathrm{mL}$, MIP-1 $\beta$ was $27.2 \mathrm{pg} / \mathrm{mL}$ [11.16-47.61] vs $0 \mathrm{pg} / \mathrm{ml}$, le TNF- $\alpha$ with $0 \mathrm{pg} / \mathrm{mL}$ [0-6.3] vs 0 $\mathrm{pg} / \mathrm{mL}$ and VEGF with $79.19 \mathrm{pg} / \mathrm{mL}$ [26.84-160.6] vs $0 \mathrm{pg} / \mathrm{mL}$.

Conversely, mean levels of IL-4, IL-7, IL-15 and PDGF-BB were significantly decreased in AH of idiopathic uveitis as compared with noninflammatory controls.

We found some patients with idiopathic uveitis and higher levels of IL-1 $\beta$, IFN- $\gamma$ and IL-23 in AH compared with noninflammatoy controls, although their median of concentration was not significantly increased compared with controls (Table 2). 
bioRxiv preprint doi: https://doi.org/10.1101/2021.08.04.455093; this version posted August $4,2021$. The copyright holder for this preprint (which was not certified by peer review) is the author/funder, who has granted bioRxiv a license to display the preprint in perpetuity. It is made available under aCC-BY 4.0 International license.

Immune mediators in idiopathic uveitis

\begin{tabular}{|c|c|c|c|}
\hline & \multicolumn{2}{|c|}{ Groups } & \multirow[b]{2}{*}{$\mathbf{P}^{*}$} \\
\hline Variable & Idiopathic uveitis, $n=75$ & $\begin{array}{c}\text { Noninflammatory controls } \\
=\text { age-related cataract } \\
\text { (without uveitis), } n=42\end{array}$ & \\
\hline IL-1 $\beta$ & $0[0-0.46]$ & $0[0-0.43]$ & 0.27 \\
\hline IL-1R $\alpha$ & $50.92[0-126.9]$ & 0.83 [0-61.69] & 0.037 \\
\hline IL-2 & $0[0-0]$ & $0[0-0]$ & 0.42 \\
\hline IL-4 & $0[0-0]$ & $0[0-0,4]$ & 0.029 \\
\hline IL-5 & $0[0-5.52]$ & $0[0-0]$ & 0.0004 \\
\hline IL-6 & $81.73[8.82-511.2]$ & $6.64[2.3-40.96]$ & 0.020 \\
\hline IL-7 & 0 [0-18.72] & $7.63[1.89-33.11]$ & 0.003 \\
\hline IL-8 & $22.23[2.12-87.86]$ & $2.76[1.62-6.36]$ & 0.002 \\
\hline IL-9 & $2.85[0-8.8]$ & $0[0-0.34]$ & 0.002 \\
\hline IL-10 & $0[0-10.18]$ & $0.35[0-2.16]$ & 0.66 \\
\hline IL-12 & $11.13[5.67-20.49]$ & $3.3[1.07-6.57]$ & $<0.0001$ \\
\hline IL-13 & $0.46[0-3.9]$ & $0.1[0-1.08]$ & 0.20 \\
\hline IL-15 & $0[0-0]$ & 0 [0-8.56] & 0.0006 \\
\hline IL-17 & 0 [0-9.96] & 0 [0-115.0] & 0.0204 \\
\hline IL-21 & 0 [0-26.09] & $0[0-0]$ & 0.12 \\
\hline IL-23 & 0 [0-4.92] & $0[0-0]$ & 0.093 \\
\hline Eotaxin & $6.29[0-30.61]$ & $0[0-0]$ & $<0.0001$ \\
\hline FGF-basic & $0[0-0]$ & $0[0-0]$ & 0.29 \\
\hline G-CSF & 9.98 [1.47-113.3] & 0.64 [0-1.89] & $<0.0001$ \\
\hline GM-CSF & 0 [0-100.4] & 0 [0-2.39] & 0.18 \\
\hline IFN- $\gamma$ & $0[0-0]$ & $0[0-0]$ & 0.066 \\
\hline IP-10 & 4442 [462.8-17790] & 284.7 [134.8-484.6] & $<0.0001$ \\
\hline MCP-1 & 125.2 [46.24-315.8] & 59 [4.11-95.26] & 0.0008 \\
\hline MIP-1 $1 \alpha$ & $1.21[0-2.66]$ & $0[0-0]$ & 0.0002 \\
\hline PDGF-bb & $0[0-0]$ & $1.69[0-13.46]$ & 0.010 \\
\hline MIP-1 $\beta$ & 27.2 [11.16-47.61] & 0 [0-7.88] & $<0.0001$ \\
\hline RANTES & $0[0-0]$ & $0[0-0]$ & 0.23 \\
\hline TNF- $\alpha$ & $0[0-6,3]$ & $0[0-0]$ & 0.004 \\
\hline
\end{tabular}


Immune mediators in idiopathic uveitis

\section{VEGF} 79.19 [26.84-160.6]

0 [0-24.37]

$<\mathbf{0 . 0 0 0 1}$

Table 2. Immune Mediator Expression in aqueous humor (AH) from 75 samples of

244 related cataract). $n=$ patients number

*Significant $P$ values are noted in right column of the Table. Statistical analysis was done with non parametric Mann-Whitney $U$ tests for the comparison of dosage of different cytokines between idiopathic uveitis and controls in aqueous humor (medianes of concentrations). A P value $<0.05$ was considered significant.

We clustered 4 subgroups of idiopathic uveitis using a statistical analysis of hierarchical unsupervised classification, characterized by the order of magnitude of concentrations of 254 intraocular cytokines (fig 4).

255 The 1st cluster (in pink in Fig. 4) presents AH cytokines concentrations slightly increased 256 (although significantly different from those found in the control group); the $2^{\text {nd }}$ cluster (in green 257 in Fig. 4) presents AH cytokines concentrations mildly increased; the $3^{\text {rd }}$ cluster (in blue in fig.

258 4) presents cytokines concentrations moderatly increased and concentrations of mediators IL259 7, IL-15 and PDGF-BB quite similar of those found in noninflammatory controls; and the $4^{\text {th }}$ 260 cluster (in black in fig. 4) presents a higher increase of levels of mediators.

261 Three patients' samples were excluded from the biostatistical analysis (fig. 4) because they 262 presented levels of mediators to high compared with the others. Those 3 patients, had idiopathic 263 uveitis of the panuveitis type (2 patients had relapsing uveitis of that kind).

264 Clinical features of the 4 clusters of patients are presented in Table 3. 


\section{Immune mediators in idiopathic uveitis}

\begin{tabular}{|c|c|c|c|c|c|}
\hline & & & Groups & & \\
\hline variable & & $\begin{array}{l}1 \\
N=26\end{array}$ & $\begin{array}{l}2 \\
\mathrm{~N}=14\end{array}$ & $\begin{array}{l}3 \\
\mathrm{~N}=8\end{array}$ & $\begin{array}{l}4 \\
=13\end{array}$ \\
\hline Sex & & $13(50 \%)$ & $6(43 \%)$ & $5(62 \%)$ & $9(69 \%)$ \\
\hline Age, median & & $\begin{array}{l}38.5 \\
{[22 ; 94]}\end{array}$ & $\begin{array}{l}43.5 \\
{[26 ; 88]}\end{array}$ & $50[20 ; 95]$ & $62[20 ; 87]$ \\
\hline eye & OD & $7(27 \%)$ & $6(43 \%)$ & $4(50 \%)$ & $3(23 \%)$ \\
\hline & OS & $4(15 \%)$ & $3(21 \%)$ & $3(38 \%)$ & $4(31 \%)$ \\
\hline $38 \%)$ & $\mathrm{OU}$ & $15(58 \%)$ & $5(36 \%)$ & $1(12 \%)$ & $6(46 \%)$ \\
\hline uveitis & intermediate & $5(19 \%)$ & $7(50 \%)$ & $3(38 \%)$ & $3(23 \%)$ \\
\hline & posterior & $16(62 \%)$ & $4(29 \%)$ & $5(62 \%)$ & $5(38 \%)$ \\
\hline & panuveitis & $5(19 \%)$ & $3(21 \%)$ & $0(0 \%)$ & $5(38 \%)$ \\
\hline vasculitis & absent & $11(42 \%)$ & $9(64 \%)$ & $5(62 \%)$ & $9(69 \%)$ \\
\hline & present & $15(58 \%)$ & $5(36 \%)$ & $3(38 \%)$ & $4(31 \%)$ \\
\hline & venous & $11(42 \%)$ & $3(21 \%)$ & $3(38 \%)$ & $3(23 \%)$ \\
\hline & arterial & $1(4 \%)$ & $0(0 \%)$ & $0(0 \%)$ & $1(8 \%)$ \\
\hline & $\begin{array}{l}\text { venous+ } \\
\text { arteriel }\end{array}$ & $3(12 \%)$ & $2(14 \%)$ & $0(0 \%)$ & $0(0 \%)$ \\
\hline $\begin{array}{l}\text { degree of } \\
\text { inflammation } \\
\text { in anterior } \\
\text { segment }\end{array}$ & $\begin{array}{l}\text { (mediane; } \\
\text { min-max) }\end{array}$ & $0[0 ; 3]$ & $0[0 ; 1]$ & $0[0 ; 0]$ & $0.5[0 ; 2]$ \\
\hline $\begin{array}{l}\text { degree of } \\
\text { inflammation } \\
\text { in vitreous }\end{array}$ & $\begin{array}{l}\text { vitritis } \\
\text { (mediane; } \\
\text { min-max) }\end{array}$ & $1[0 ; 3]$ & $0.75[0 ; 2]$ & $1[0 ; 2]$ & $1[0 ; 4]$ \\
\hline $\begin{array}{l}\text { choroidal } \\
\text { granulomas }\end{array}$ & yes & $2(8 \%)$ & $1(7 \%)$ & $0(0 \%)$ & $2(15 \%)$ \\
\hline CME & yes & $5(19 \%)$ & $7(50 \%)$ & $2(25 \%)$ & $5(42 \%)$ \\
\hline papillitis & yes & $2(8 \%)$ & $6(43 \%)$ & $1(12 \%)$ & $4(31 \%)$ \\
\hline \multirow{3}{*}{$\begin{array}{l}\text { course } \\
\text { episode }\end{array}$} & acute & $11(42 \%)$ & $3(21 \%)$ & $5(62 \%)$ & $5(38 \%)$ \\
\hline & relapsing & $7(27 \%)$ & $3(21 \%)$ & $1(12 \%)$ & $5(38 \%)$ \\
\hline & chronic & $8(31 \%)$ & $8(57 \%)$ & $2(25 \%)$ & $3(28 \%)$ \\
\hline
\end{tabular}


Immune mediators in idiopathic uveitis

Tableau 3. Comparison between 4 sub-groups patients with idiopathic uveitis $(n=64 *)$ and their clinical parameters.

$302 *$ Three patients were excluded because of very high levels of chemokines/ cytokines (see fig. 3). Those patients

303 had no common clinical signs excepted their age: one patient was 14 yo and 2 patients were respectively 66 and 78 yo. Both latter patients experienced relapsing uveitis episodes.

We compared the median $\mathrm{AH}$ concentrations of cytokines and chemokines between noninflammatory controls and patients with uveitis related to Behçet disease, sarcoidosis, TU and idiopathic uveitis (fig 5) for those 4 mediators significantly elevated in idiopathic uveitis as compared as noninflammatory controls: IL-6, TNF- $\alpha$, IL-12 and IP-10. IL-6, TNF- $\alpha$ and P10 were found significantly elevated in the $\mathrm{AH}$ of patients with uveitis related to Behçet disease, sarcoidosis and TU as compared with noninflammatory controls. IL-12 was found elevated in all uveitis causes as compared as noninflammatory controls excepted in TU. We further compared the same cytokines and chemokines (IL-6, TNF- $\alpha$, IL-12 et IP-10), between noninflammatory controls with uveitis related to sarcoidosis, TU and idiopathic uveitis with the exclusion of Behçet disease related uveitis, due to too disparate orders of values (fig 6): AH contained much higher levels of those mediators in Behçet disease as compared as the other causes of uveitis (fig 6).

We compared the 4 subgroups of idiopathic uveitis defined by the statistical method shown in Figure 4.

321 The first group had relatively weak cytokine values, although significantly different from those of the control ('idiop 1'); A 2nd group presents high moderately cytokine values ('idiop 2') ; A 3rd group, high moderately cytokine values (IL-6, TNF- $\alpha$, IP-10) except for the IL-12, which is very high ('idiop 3') ; and finally, a 4th group has very high cytokines and chemokines values ('idiop 4').

Table 4 summarizes the immune mediators expression in idiopathic uveitis and diseases 
bioRxiv preprint doi: https://doi.org/10.1101/2021.08.04.455093; this version posted August $4,2021$. The copyright holder for this preprint (which was not certified by peer review) is the author/funder, who has granted bioRxiv a license to display the preprint in perpetuity. It is made available under aCC-BY 4.0 International license.

Immune mediators in idiopathic uveitis

\begin{tabular}{|c|c|c|c|}
\hline \multicolumn{4}{|c|}{ Infectious uveitis } \\
\hline Toxoplasmosis & 27 cytokines & serum $(n=16)$ & $\mathrm{AH}(n=11)$ \\
\hline & & IL-2, GM-CSF (1) & $\begin{array}{l}\text { G-CSF, IFN- } \gamma, \text { IP-10 (9) } \\
\text { eotaxin (7) } \\
\text { MCP-1 et TNF- } \alpha \text { (5) } \\
\text { IL-8 (4) } \\
\text { IL-4 (3) } \\
\text { IL-1 } \beta \text {, IL-6, IL-9, IL-10, IL-12, } \\
\text { IL-13, MIP-1a, PDGF-BB, VEGF } \\
\text { (2) } \\
\text { IL-1Ra, IL-2, IL-17, RANTES, } \\
\text { VEGF (1) }\end{array}$ \\
\hline & $\begin{array}{l}\text { cytokines } \\
\text { IL-21, IL-23 }\end{array}$ & serum $(n=14)$ & $\mathrm{AH}(n=3)$ \\
\hline & & none & IL-21 (1) \\
\hline \multicolumn{4}{|c|}{ noninfectious uveitis } \\
\hline \multirow[t]{4}{*}{ sarcoidosis } & 27 cytokines & serum $(n=12)$ & $\mathrm{AH}(n=15)$ \\
\hline & & $\begin{array}{l}\text { IL-1 } \beta, \text { IL-1Ra, IL-2, IL-6, } \\
\text { éotaxine, } \\
\text { G-CSF, GM-CSF, IP-10, } \\
\text { IFN- } \gamma, \\
\text { MIP-1b, TNF- } \alpha(1)\end{array}$ & 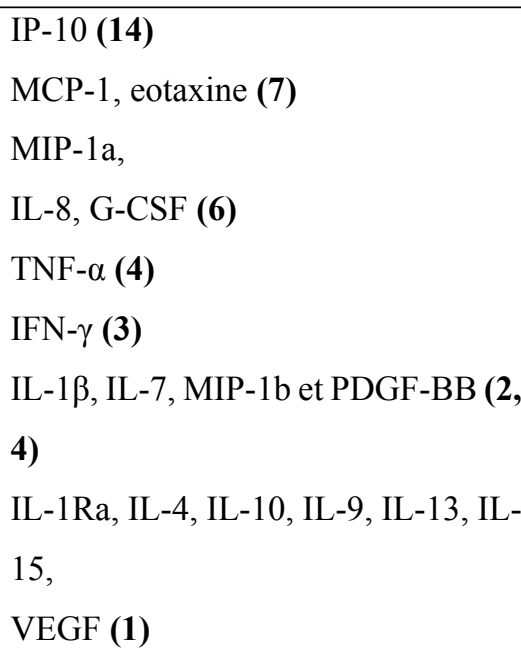 \\
\hline & $\begin{array}{l}\text { cytokines } \\
\text { IL-21, IL-23 }\end{array}$ & serum $(n=14)$ & $\mathrm{AH}(n=3)$ \\
\hline & & none & none \\
\hline \multirow[t]{2}{*}{ Behcet } & 27 cytokines & serum $(n=7)$ & $\mathrm{AH}(n=5)$ \\
\hline & & IL-1 $\beta$ (2) & $\begin{array}{l}\text { IP-10 (5) } \\
\text { IL-6, IL-8, G-CSF, MCP-1 (4) } \\
\text { IL-1 } \beta, \text { IL-1R } \alpha \text {, IL-7, IL-9, IL-12, IL- } \\
\text { 13, eotaxin, IFN- } \gamma \text {, MIP-1 } \alpha \text {, PDGF- } \\
\text { BB, TNF- } \alpha \text { (3) }\end{array}$ \\
\hline
\end{tabular}


Immune mediators in idiopathic uveitis

\begin{tabular}{|c|c|c|c|}
\hline & $\begin{array}{l}\text { cytokines } \\
\text { IL-21, IL-23 }\end{array}$ & serum $(n=6)$ & $\mathrm{AH}(n=1)$ \\
\hline & & none & none \\
\hline \multirow{4}{*}{$\begin{array}{l}\text { idiopathic } \\
\text { uveitis }\end{array}$} & 27 cytokines & serum $(n=63)$ & $\mathrm{AH}(n=69)$ \\
\hline & & 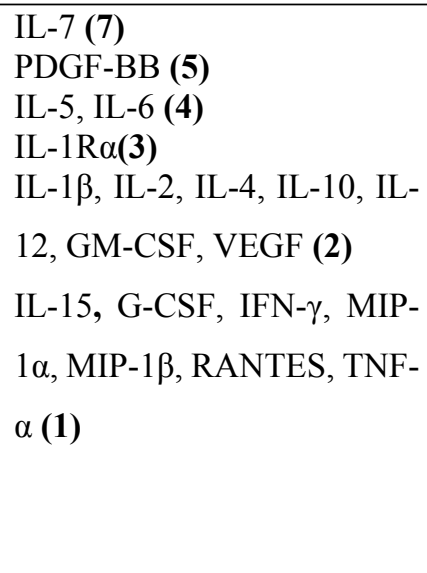 & $\begin{array}{l}\text { IL-12 (36) } \\
\text { IP-10 (32) } \\
\text { G-CSF (29) } \\
\text { IL-5 (26) } \\
\text { IL-10 (22) } \\
\text { VEGF (21), MCP-1 (18) } \\
\text { IL-6 (15), IL-8, TNF- } \alpha \text { (14) } \\
\text { IL-13 (12), FGF-b (10), IL-17 (10) } \\
\text { IL-12, MIP-1 } \alpha, \text { GM-CSF, PDGF-BB } \\
\text { (8) } \\
\text { IL-1R } \alpha(5), \text { MIP-1 } \beta, \text { (7), RANTES } \\
\text { (6) } \\
\text { IL-2 (4), IL-4, IFN- } \gamma \text { (3), IL-1 } \beta \text { (2), } \\
\text { IL-7 (1) }\end{array}$ \\
\hline & $\begin{array}{l}\text { cytokines } \\
\text { IL-21, IL-23 }\end{array}$ & serum $(n=68)$ & $\mathrm{AH}(n=58)$ \\
\hline & & $\begin{array}{l}\text { IL-21 (38) } \\
\text { IL-23 (6) }\end{array}$ & IL-21, IL-23 (16) \\
\hline
\end{tabular}

Table 4. Immune mediator expression (cytokines, chemokines and growth factors) elevated in patients with idiopathic uveitis and disease control groups (infectious and

\section{- Discussion}

340 In our study, the analysis of AH samplings from patients with idiopathic uveitis confirmed

341 elevated levels of cytokines and chemokines mostly of inflammatory type as compared with 342 noninflammatory controls. In that, our study is in accordance with previous studies [11], [12].

343 In particular, idiopathic uveitis seems being associated with higher AH levels of the following 344 immune mediators: IL-1R $\alpha$, IL-6, IL-8, IL-12, IL-17, IP-10, MIP-1 $\alpha$, MIP-1 $\beta$, MCP-1, G-CSF and TNF- $\alpha$. We also found other mediators elevated, IL-5 and IL-9.

Few studies have considered cytokines in the patients with idiopathic uveitis localized in the intermediate segment of the eye without really distinguishing those entities from others such as multiple sclerosis, sarcoidosis and Lyme borreliosis. In particular, higher AH levels have 
been shown for IL-1 $\beta$, IL-6, IL-8, IL-10, IL-12(p70), IFN $\gamma$ and CCL2/MCP-1 as compared with noninflammatory controls [12].

In our knowledge, no study has focused specifically on idiopathic uveitis and their immune mediators.

- Th1 cytokines (TNF- $\alpha$, IFN- $\gamma$ and IL-12); IFN- $\gamma$-inducing cytokine (IL-12) and IFN- $\gamma$-inducible CXC chemokine (IP-10) :

We confirmed common knowledge that some patients with idiopathic uveitis have increased AH level of IFN- $\gamma$. In our study, median of concentrations of INF- $\gamma$ was not significantly elevated in the whole cohort of patients with idiopathic uveitis but three patients had AH levels higher than the cut-off as defined in noninflammatory controls (cut-off $=$ mean +3 standard deviations). Previous studies have shown significantly AH elevated IFN- $\gamma$ in patients with idiopathic anterior uveitis of anterior and intermediate anatomical type [11], [13]-[15]. In herpetic viral etiology, mean level of IFN- $\gamma$ is higher than in other viral uveitis and in noninfectious uveitis [16], [17].

In our study, IL-12 was the cytokine most commonly elevated in patients with idiopathic uveitis and its median level was also elevated in the AH. IL-12 is an immunoregulatory cytokine which plays a key role in the polarization of the naïve Th cells [18]. IL-12 is produced by macrophages and dendritic cells. Our results regarding IL-12 confirms the immune mechanism Th1 serving a preponderant role in human uveitis [19]. IL-12p70 has been shown to influence IFN- $\gamma$ production [20]. Although intraocular levels of IL-12 have been shown higher in patients with intermediate uveitis than in noninflammatory controls' eyes, those levels were not correlated to the activity of the disease in those previous studies [18], [21]-[23].

We found elevated median levels of IP-10 in the AH and the serum of patients with idiopathic uveitis. IP-10 is linked to the monokines induced by IFN- $\gamma$ (IFN- $\gamma$-inducible CXC chemokine) et to the IFN-inducible T cell $\alpha$ chimioattractant, that controls the migration and adhesion of activated T cells and NK cells [24]. The IP-10 expression is increased in various cells, including endothelial cells, keratinocytes, fibroblastes, astrocytes, moncytes and neutrophiles by stimulation of IFN- $\alpha$, IFN- $\beta$, IFN- $\gamma$, LPS and in T cells by antigen activation 380 [25]. IP-10 is also expressed in many Th1 mediated human diseases. IP-10 levels are correlated 381 to the infiltration by the T cells suggesting that IP-10 plays a role in the attraction of $\mathrm{T}$ cells towards the sites of inflammation [26],[27]. IP-10 is also a chemoattractant for 
monocytes/macrophages, NK cells and dendritic cells. IP-10 levels have previously been found increased in uveitis associated with tuberculosis but is also known to be elevated in other infections (HIV, Leishmaniasis) [28],[29].

These data show that increased levels in HA of mediators involved in the production and the activity of IFN- $\gamma$ may play an important immunopathogenic role in idiopathic uveitis.

The median level of TNF- $\alpha$ of increased in our study representing 14 among 69 (20\%) of the AH samples from the patients with idiopathic uveitis. TNF- $\alpha$, is essential for the induction and maintenance of inflammation in the autoimmune reactions and is released by macrophages and $\mathrm{T}$ lymphocytes during the inflammatory response. It affects the activation of leukocytes and their infiltration by hyperregulation of adhesions molecules and activation of macrophages. It also drives the lymphocytic Th1 response in the tissues [30]. There are discordant previous results as regards to AH levels of TNF- $\alpha$ in idiopathic uveitis. For Valentincinc et al, the TNF- $\alpha$ levels in active idiopathic uveitis and in the anatomic intermediate uveitis type, did not seem being increased [11], conversely to an other report of noninfectious uveitis [16]. Other studies concerning intermediate idiopathic uveitis showed the proinflammatory cytokine TNF- $\alpha$, elevated in serum rather than in the AH [11].The proinflammatory cytokine TNF- $\alpha$, released by macrophages, monocytes and the T cells, plays a key role in the inflammatory process and the maintain of the autoimmune reactions [30]. It has been previously shown that TNF- $\alpha$ might contribute to the hemato-retinal barrier breakdown during uveitis, possibly through mechanisms involving endothelial cells [31].

We found IL-2 increased in only 2 AH samples from patients with idiopathic uveitis. However, IL-2 has been found previously in the choroid and AH of patient with idiopathic uveitis and their serum levels were correlated with the levels in $\mathrm{AH}$ and an increase of the $\mathrm{CD}^{+}$ $\mathrm{T}$ cell subset expressing IL-2R in the peripheral blood [32].

\section{- Th17 cytokines (IL-17A, IL-17F, IL-21, IL-22 and IL-23) :}

We found in patients with idiopathic uveitis that IL-17 was significantly elevated in both serum and AH and IL-21 in the serum. In regard to the serum analysis, the Th17 pathway seems critical in most of the idiopathic uveitis. IL-21 can drive the differentiation and production of Th17 [33] and it attracts the leukocytes in the lesions of the central nervous system like in Behcet disease [34]. It seems that some idiopathic uveitis might be associated to a concomittant active systemic inflammation, of Th17 nature, that is herein also found in the 
serum samples. In sarcoidosis, IL-17 elevated levels have been described in the serum [35]. Elevated levels of IL-17 and IL-21 have been previously described in birdshot chorioretinopathy and in Vogt-Koyanagi-Harada disease [36], [37].

418 IL-17 is produced by a subset of CD4+ cells refered to as Th17 cells but also by T CD8 ${ }^{+}$cells 419 [38], NK cells [39] and by $\gamma \delta$ lymphocytes [40]. We also found IL-17 elevated in 10 out of 69 AH samples (14.5\%). IL-17 controls the expression of cells that express the IL-17 receptor (IL17R). IL-17R responds by increased secretion of IL-6, IL-8, MCP-1 and G-CSF with the induction of a chronic inflammation with monocytes and macrophages infiltrates [41]. This might correspond to the pathophysiological mechanism of idiopathic uveitis because we demonstrated elevated median levels of IL-6, de MCP-1 and G-CSF in the AH. The higher levels of MCP-1 in AH had been previously described in idiopathic uveitis but in the anatomical type of intermediate uveitis only [11].

In $10 \mathrm{AH}$ samples among the 69 that were tested in our study, IL-10 levels were found (14.5\%) elevated. Although IL-10 levels were lower than IL-6 excluding the differential diagnosis of primary ocular lymphoma [42]. This is in disagreement with a previous study that showed that IL-10 levels were similar to the noninflammatory controls' [10]. IL-10 is an antiinflammatory cytokine that supresses the expression of pro-inflammatory chemokines and cytokines TNF- $\alpha$, IFN- $\gamma$ and IL-1 $\beta$ [43], adhesion molecules, as well as antigen-presenting and costimulatory molecules in monocytes/macrophages, neutrophils, and T cells [44]. A previous study has shown IL-10 elevated in 3 among the 22 AH samples from idiopathic uveitis that might reflect the immunoregulator role of this cytokine [10]. This corresponds to a control of inflammatory process in correlation with elevated levels of IL-6 [16], [42], [45].

We found the median levels of IL-9 (a Th9 cell-specific cytokine) elevated in the AH of idiopathic uveitis. Th9 cells are a sub-population of $\mathrm{CD}^{+} \mathrm{T}$ cells and they produce IL-9 and IL-10 in the presence of IL-4 and TGF- $\beta$ [46], [47]. Mouse models have indicated a role for Th9 cells in immunity and immune-mediated disease and recent studies have indicated that IL9-producing cells contribute to a group of autoimmune and chronic inflammatory disorders including systemic lupus erythematosus (SLE), multiple sclerosis (MS), inflammatory bowel 
Immune mediators in idiopathic uveitis

diseases (IBD), rheumatoid arthritis (RA), asthma and psoriasis [48, 49,50]. To our knowledge we are the fist to report increased IL-9 levels in HA in idiopathic uveitis.

\section{- Other chemokines and cytokines}

A previous study has shown a positive correlation between the different cytokines, chemokines being elevated (IL-6, IL-8, MCP-1, and IFN- $\gamma$ ), in the AH of patients with idiopathic uveitis [10]. We confirmed an increase of median levels of IL-6, IL-8 and MCP-1.

We confirmed the findings of elevated median levels of IL-8 in 15 AH samplings from patients with idiopathic uveitis as previously demonstrated in intermediate uveitis of idiopathic origins [11] but also in Behcet disease and in active noninfectious uveitis [51]. IL-8 has a role in the neutrophils activation and in leukocytes migration into inflamed tissues. Moreover, IL-8 induces the differentiation of mononuclear cells into infiltrative granulocytes and the adhesion of leukocytes from the peripheral blood to the endothelial cells. In previous studies, the increase of IL-8 in the ocular form of Behcet disease has been shown as having the role to attract the polymorphonuclear neutrophils towards the lesions [52,53].

The median levels of IL- 6 were elevated in the AH from patients with idiopathic uveitis. This is in agreement with previous studies that showed an increase of IL-6 in the anatomical types of anterior uveitis [10], [54], [55]. Herein, we were able to demonstrate that increase of IL-6 also in intermediate, posterior and panuveitis. IL-6 is pleiotropic and proinflammatory produced by $\mathrm{T}$ cells, monocytes, macrophages and synovial fibroblastes. This cytokine is involved in the Th17 cells differentiation by regulating the balance between Th17 lymphocytes and Treg cells and is also involved in suppressing the differentiation [56]. IL-6 increases the vascular permeability and the angiogenesis. IL-6, IL-8 and MCP-1 have been shown as regulated by the nuclear factor NF-kB pathway that plays a key role in the immune response [57]. Previous study have shown increased IL-6 and IL-8 in the intraocular samples of patients with TU, viral uveitis, Fuchs iridocyclitis, ocular Behcet disease and pediatrics uveitis [10], [58].

We found G-CSF median levels elevated in the AH of patients with idiopathic uveitis. Increased G-CSF have also been found in serum and synovial fluid of patients rheumatoid arthritis and correlated with disease severity [59]. Adding G-CSF increases the number of neutrophils in the serum and the endogenous G-CSF is important for the basal granulopoiesis. The infiltration of target tissues by the recruitment of neutrophils during inflammation is 
480

481

482

483

484

485

486

487

488

489

490

491

492

493

494

495

496

497

498

499

500

501

502

503

504

505

506

507

508

509

510

511

512

characteristic in both acute and chronic settings and the leukocytes population is mostly polynuclear neutrophils found in the inflammed joints in rheumatoid arthritis, for instance [60]. G-CSF acts as an activator of human granulocytes migration towards the tissues [61].

We found median levels of MCP-1 (CCL-2) elevated in the AH of patients with idiopathic uveitis in our study. MCP-1 is one of the key chemokines that regulate migration and infiltration of monocytes/macrophages into foci of active inflammation [62].

We found in the $\mathrm{AH}$ from patients with idiopathic uveitis, an elevated median level of IL-5. IL-5 is a cytokine produced by Th2 activated lymphocytes and mastocytar cells that selectively stimulate the differentiation, proliferation and fonctionnal activation of eosinophils. In Takase et al's study, IL-5 was detected in the AH samples from patients with viral acute retinal necrosis and in patients with anterior uveitis related to herpesvirus. IL-5 was not detected in noninfectious uveitis [16].

In our study IL-1 $\beta$ was elevated in 3 out of 69 samples from patients with idiopathic uveitis only (4\%). IL-1 $\beta$ acts locally like an amplification signal in the pathological process associated with chronic inflammation as show previously in the vitreous from patients with idiopathic panuveitis [63].

As regards to the chemokines and cytokines found in the serum, some isolated patients with idiopathic uveitis had some other mediators elevated apart from IL-17, IP-10 and IL-21. Those mediators were the following ones: IL-1 $\beta$, IL-1R $\alpha$, IL-2, IL-4, IL-6, IL-7, IL-10, IL-12, IL-15, IFN- $\gamma$, G-CSF, MIP-1 $\alpha$, MIP-1 $\beta$, TNF- $\alpha$, RANTES, PDGF-BB and VEGF, meaning that various sub-groups in idiopathic uveitis might exist. We also present data on increased ocular concentrations of IFN- $\gamma$-inducing cytokine (IL-12) and IFN- $\gamma$-inducible CXC chemokine (IP10), suggesting that IFN plays a central role in cellular immunity. In our study, this hypothesis was also suspected by the statistical analysis of hierarchical unsupervised classification, that described 4 subgroups (or clusters) of idiopathic uveitis characterized by the order of magnitude of concentrations of intraocular cytokines.

\section{Conclusion}

Idiopathic uveitis in humans has long been considered as a Th1-mediated disease, with interferon (IFN)- $\gamma$ and IL-12 as signature cytokines. We confirm this findings in idiopathic uveitis of the intermedicate and posterior anatomical types because we found IFN- $\gamma$ increased in the AH samples tested. In several causes of uveitis however, it has been shown that both 
513 innate and adaptive immunity, leading to the activation of the IL-23/Th17 axis, may contribute

514 to the initiation of tissue inflammation. The inflammatory mechanisms in the cases of idiopathic uveitis are possibly mediated by the Th17 pathway because we demonstrated IL-17 elevated in both AH and serum and IL-21 elevated in the serum.

517 In our present study, IL-9 has been also demonstrated to be probably involved in the 518 pathogenesis of idiopathic uveitis because we demonstrated IL-9 levels being elevated in the $\mathrm{AH}$ as it has been shown in other chronic inflammatory disease but also of auto-immune pathogenesis. In particular, Th9 cells are also increased in the skin lesions of psoriasis and in rheumatoid arthritis synovial tissues and their aberrant activation may contribute to those inflammatory diseases. Other proinflammatory (IL-6, IL-8, IP-10, MCP-1, G-CSF, MIP-1 $\alpha$ et MIP-1 $\beta$ et TNF- $\alpha$ ) and antiinflammatory (IL-1R $\alpha$ ) immune mediators were increased in AH samples from idiopathic uveitis. Moreover, we also demonstrated in the serum samples of patients with idiopathic uveitis elevated levels of IL-17, IL-21 and IP-10 that might imply a systemic immune mechanism for some of them instead of a purely ocular limited disease as suggested by the clinical examination.

Those results can have implications of anti-cytokine therapies in uveitis and autoimmune diseases with uveitic symptoms.

\section{FIGURES CAPTIONS}

Figure 1. Dot plots of immune mediators : IL-17 and IP-10 in the serum, increased in patients with idiopathic uveitis $(n=63)$ compared with serum of noninflammatory controls patients (cataract age-related) (CTL) ( $\mathrm{n}=47)$. Medians levels for IL-21 and IL-23 in the serum: elevated for IL-21 and decreased for IL-23 in patients with idiopathic uveitis $(\mathrm{N}=68)$ as compared with noninflammatory controls patients (cataract age-related) (CTL) $\quad(\mathrm{N}=16) . \quad *=\mathrm{P}<0.05$; $* *=\mathrm{P}<0.01 ; * * *=\mathrm{P}<0.001$.

540 Figure 2. Dot plots of immune mediators: IL-1 $\beta$, IL-6, IFN- $\gamma$ and TNF- $\alpha$ in serum of noninflammatory controls patients (cataract age-related) (CTL) $(\mathrm{N}=36)$ as compared with immune mediators in the serum of patients with idiopathic uveitis $(n=51)$ but differences in

543 both groups are not significant. Note that few isolated patients with idiopathic uveitis had cytokines increased in serum samples. ${ }^{*}=\mathrm{P}<0.05 ; * *=\mathrm{P}<0.01 ; * * *=\mathrm{P}<0.001$. 
Figures 3 a-e. Dot plots of immune mediators: IL-1 $\beta$, IL1-R $\alpha$, IL-6, IL-8, IL-10, IL-12, IL-17, aqueous humor of patients with idiopathic uveitis $(\mathrm{N}=64)$ as compared with immune mediators in the aqueous humor of noninflammatory controls patients (cataract age-related) $(\mathrm{N}=36)$. Note that few isolated patients with idiopathic uveitis had an immune mediator elevated. $*=\mathrm{P}<0.05 ; * *=\mathrm{P}<0.01 ; * * *=\mathrm{P}<0.001$.

Figure 4: Heat map of aqueous humor cytokine concentrations compared in 64 of the idiopathic uveitis samples with 47 of controls age-related cataracts. Only significant different cytokines in idiopathic uveitis compared with controls were considered. Cytokine concentrations are depicted as colors ranging from red to orange to yellow, indicating low, intermediate, and high concentration, respectively, relative to the mean cytokine concentration. The phenotype of the samples is indicated by the label on the right as well as by the colored bar on the top. Samples are separated in one of four clusters (pink, green, blue and black) indicated on the top.

Figure 5. Boxplots of 4 immune mediators significantly elevated in the aqueous humor of patients with idiopathic uveitis (Idiop) : IL-6, TNF- $\alpha$, IL-12 and IP-10, as compared to immune mediators in the aqueous humor of patients with uveitis related to Behçet disease, sarcoidosis, TU (Toxo) and noninflammatory controls (T). Significant $\mathrm{P}$ values are noted in the upper part of each graph. A P value $<0.05$ was considered significant.

Figure 6. Boxplots of 4 immune mediators significantly elevated in the aqueous humor of patients within 4 sub-groups of idiopathic uveitis (Idiop 1, 2, 3 and 4) : IL-6, TNF- $\alpha$, IL-12 and IP-10, as compared to immune mediators in the aqueous humor of patients with uveitis related to sarcoidosis, TU (Toxo) and noninflammatory controls (T). Significant P values are noted in the upper part of each graph. A P value $<0.05$ was considered significant. 
bioRxiv preprint doi: https://doi.org/10.1101/2021.08.04 455093; this version posted August 4 2021. The copyright holder for this preprint (which was not certified by peer review) is the author/funder, who has granted bioRxiv a license to display the preprint in perpetuity. It is made available under aCC-BY 4.0 International license.

Immune mediators in idiopathic uveitis

580

581

582

583

584

\section{Acknowledgments}

Dr Sabrina Falah, Dr Auclin, Dr Bottin, Dr Raphaelle Ores, Clémence Virevialle, Dr Jonathan

Benesty, Dr Jad Akesbi, Dr Antoine Labbe, Dr Raphael Adam, Dr Tibault Rodallec, Dr Lyes

Meziani, Ms Claire Poilane, Mr Didier Gleize, Miss Hélène Segara, Mr. Frédéric Diefhental

\section{REFERENCES}

1. Luger D, Caspi RR. New perspectives on effector mechanisms in uveitis. Semin Immunopathol. 2008 Apr;30(2):135-43

2. Luger D, Caspi RR. New perspectives on effector mechanisms in uveitis. Semin Immunopathol. 2008 Apr;30(2):135-43.

3. Caspi RR. Ocular autoimmunity: the price of privilege? Immunol Rev. 2006 Oct;213:2335.

4. Caspi RR, Sun B, Agarwal RK, Silver PB, Rizzo LV, Chan CC, Wiggert B, Wilder RL. $\mathrm{T}$ cell mechanisms in experimental autoimmune uveoretinitis: susceptibility is a function of the cytokine response profile. Eye (Lond). 1997;11 (Pt 2):209-12.

5. de Kozak Y, Naud MC, Bellot J, Faure JP, Hicks D. Differential tumor necrosis factor expression by resident retinal cells from experimental uveitis-susceptible and -resistant rat strains. J Neuroimmunol. 1994 Nov;55(1):1-9

6. Chua J, Vania M, Cheung CM, Ang M, Chee SP, Yang H, Li J, Wong TT. Expression profile of inflammatory cytokines in aqueous from glaucomatous eyes. Mol Vis. 2012;18:431-8

7. Abcouwer SF. Angiogenic Factors and Cytokines in Diabetic Retinopathy. J Clin Cell Immunol. 2013; Suppl 1(11):1-12

8. de Parisot A, Kodjikian L, Errera MH, Sedira N, Heron E, Pérard L, Cornut PL, Schneider C, Rivière S, Ollé P, Pugnet G, Cathébras P, Manoli P, Bodaghi B, Saadoun D, Baillif S, Tieulie N, Andre M, Chiambaretta F, Bonin N, Bielefeld P, Bron A, Mouriaux F, Bienvenu B, Vicente S, Bin S, Broussolle C, Decullier E, Sève P; ULISSE group. Randomized Controlled Trial Evaluating a Standardized Strategy for Uveitis Etiologic Diagnosis (ULISSE). Am J Ophthalmol. 2017 Jun;178:176-185

9. Jabs DA, Nussenblatt RB, Rosenbaum JT; Standardization of Uveitis Nomenclature (SUN) Working Group. Standardization of uveitis nomenclature for reporting clinical data. Results of the First International Workshop. Am J Ophthalmol. 2005 Sep;140(3):509-16

10. Herbort CP, Rao NA, Mochizuki M; members of Scientific Committee of First International Workshop on Ocular Sarcoidosis. International criteria for the diagnosis of ocular sarcoidosis: results of the first International Workshop On Ocular Sarcoidosis (IWOS). Ocul Immunol Inflamm. 2009 May-Jun;17(3):160-9

11. Curnow SJ, Falciani F, Durrani OM, Cheung CM, Ross EJ, Wloka K, Rauz S, Wallace GR, Salmon M, Murray PI. Multiplex bead immunoassay analysis of aqueous humor reveals distinct cytokine profiles in uveitis. Invest Ophthalmol Vis Sci. 2005 Nov;46(11):4251-9 
bioRxiv preprint doi: https://doi.org/10.1101/2021.08.04.455093; this version posted August 4 , 2021. The copyright holder for this preprint (which was not certified by peer review) is the author/funder, who has granted bioRxiv a license to display the preprint in perpetuity. It is made available under aCC-BY 4.0 International license.

Immune mediators in idiopathic uveitis

12. Valentincic NV, de Groot-Mijnes JD, Kraut A, Korosec P, Hawlina M, Rothova A. Intraocular and serum cytokine profiles in patients with intermediate uveitis. Mol Vis. 2011;17:2003-10.

13. Abi-Hanna D, McCluskey P, Wakefield D. HLA antigens in the iris and aqueous humor gamma interferon levels in anterior uveitis. Invest Ophthalmol Vis Sci. 1989 May;30(5):990-4.

14. Muhaya M, Calder V, Towler HM, Shaer B, McLauchlan M, Lightman S. Characterization of $\mathrm{T}$ cells and cytokines in the aqueous humour $(\mathrm{AH})$ in patients with Fuchs' heterochromic cyclitis (FHC) and idiopathic anterior uveitis (IAU). Clin Exp Immunol. 1998 Jan;111(1):123-8.

15. Muhaya M, Calder VL, Towler HM, Jolly G, McLauchlan M, Lightman S. Characterization of phenotype and cytokine profiles of T cell lines derived from vitreous humour in ocular inflammation in man. Clin Exp Immunol. 1999 Jun;116(3):410-4.

16. Takase H, Futagami Y, Yoshida T, Kamoi K, Sugita S, Imai Y, Mochizuki M. Cytokine profile in aqueous humor and sera of patients with infectious or noninfectious uveitis. Invest Ophthalmol Vis Sci. 2006 Apr;47(4):1557-61

17. de Visser L, H de Boer J, T Rijkers G, Wiertz K, van den Ham HJ, de Boer R, M van Loon A, Rothova A, de Groot-Mijnes JD. Cytokines and Chemokines Involved in Acute Retinal Necrosis. Invest Ophthalmol Vis Sci. 2017 Apr 1;58(4):2139-2151

18. Yoshida A, Koide Y, Uchijima M, Yoshida TO. IFN-gamma induces IL-12 mRNA expression by a murine macrophage cell line, J774. Biochem Biophys Res Commun. 1994 Feb 15;198(3):857-61

19. de Smet MD, Chan CC. Regulation of ocular inflammation--what experimental and human studies have taught us. Prog Retin Eye Res. 2001 Nov;20(6):761-97.

20. Lauw FN, Simpson AJ, Prins JM, Smith MD, Kurimoto M, van Deventer SJ, Speelman P, Chaowagul W, White NJ, van der Poll T. Elevated plasma concentrations of interferon (IFN)-gamma and the IFN-gamma-inducing cytokines interleukin (IL)-18, IL-12, and IL-15 in severe melioidosis. J Infect Dis. 1999 Dec;180(6):1878-85

21. Akpek EK, Maca SM, Christen WG, Foster CS. Elevated vitreous interleukin-10 level is not diagnostic of intraocular-central nervous system lymphoma. Ophthalmology. 1999 Dec;106(12):2291-5

22. el-Shabrawi Y, Livir-Rallatos C, Christen W, Baltatzis S, Foster CS. High levels of interleukin-12 in the aqueous humor and vitreous of patients with uveitis. Ophthalmology. 1998 Sep;105(9):1659-63

23. El-Asrar AM, Struyf S, Kangave D, Al-Obeidan SS, Opdenakker G, Geboes K, Van Damme J. Cytokine profiles in aqueous humor of patients with different clinical entities of endogenous uveitis. Clin Immunol. 2011 May;139(2):177-84

24. Loetscher P, Seitz M, Clark-Lewis I, Baggiolini M, Moser B. Activation of NK cells by CC chemokines. Chemotaxis, Ca2+ mobilization, and enzyme release. J Immunol. 1996 Jan $1 ; 156(1): 322-7$

25. Vanguri P, Farber JM. Identification of CRG-2. An interferon-inducible mRNA predicted to encode a murine monokine. J Biol Chem. 1990 Sep 5;265(25):15049-57. PMID: 2118520. 26. Agostini C, Calabrese F, Rea F, Facco M, Tosoni A, Loy M, Binotto G, Valente M, Trentin L, Semenzato G. Cxcr3 and its ligand CXCL10 are expressed by inflammatory cells infiltrating lung allografts and mediate chemotaxis of T cells at sites of rejection. Am J Pathol. 2001 May;158(5):1703-11

27. Melter M, Exeni A, Reinders ME, Fang JC, McMahon G, Ganz P, Hancock WW, Briscoe DM. Expression of the chemokine receptor CXCR3 and its ligand IP-10 during human cardiac allograft rejection. Circulation. 2001 Nov 20;104(21):2558-64 
bioRxiv preprint doi: https://doi.org/10.1101/2021.08.04.455093; this version posted August 4 , 2021. The copyright holder for this preprint (which was not certified by peer review) is the author/funder, who has granted bioRxiv a license to display the preprint in perpetuity. It is made available under aCC-BY 4.0 International license.

Immune mediators in idiopathic uveitis

28. Mhandire K, Mlambo T, Zijenah LS, Duri K, Mateveke K, Tshabalala M, Mhandire DZ, Musarurwa C, Wekare PT, Mazengera LR, Matarira HT, Stray-Pedersen B. Plasma IP-10 Concentrations Correlate Positively with Viraemia and Inversely with CD4 Counts in Untreated HIV Infection. Open AIDS J. 2017 Apr 26;11:24-31 29. Hailu A, van der Poll T, Berhe N, Kager PA. Elevated plasma levels of interferon (IFN)gamma, IFN-gamma inducing cytokines, and IFN-gamma inducible CXC chemokines in visceral leishmaniasis. Am J Trop Med Hyg. 2004 Nov;71(5):561-7.

30. Suhler EB, Smith JR, Giles TR, Lauer AK, Wertheim MS, Kurz DE, Kurz PA, Lim L, Mackensen F, Pickard TD, Rosenbaum JT. Infliximab therapy for refractory uveitis: 2year results of a prospective trial. Arch Ophthalmol. 2009 Jun;127(6):819-22.

31. Luna JD, Chan CC, Derevjanik NL, Mahlow J, Chiu C, Peng B, Tobe T, Campochiaro PA, Vinores SA. Blood-retinal barrier (BRB) breakdown in experimental autoimmune uveoretinitis: comparison with vascular endothelial growth factor, tumor necrosis factor alpha, and interleukin-1beta-mediated breakdown. J Neurosci Res. 1997 Aug 1;49(3):26880 .

32. Feron EJ, Calder VL, Lightman SL. Oligoclonal activation of CD4+ T lymphocytes in posterior uveitis. Clin Exp Immunol. 1995 Mar;99(3):412-8

33. Horai R, Caspi RR. Cytokines in autoimmune uveitis. J Interferon Cytokine Res. 2011 Oct;31(10):733-44

34. Brüstle A, Heink S, Huber M, Rosenplänter C, Stadelmann C, Yu P, Arpaia E, Mak TW, Kamradt $\mathrm{T}$, Lohoff $\mathrm{M}$. The development of inflammatory $\mathrm{T}(\mathrm{H})-17$ cells requires interferon-regulatory factor 4. Nat Immunol. 2007 Sep;8(9):958-66

35. Jawad S, Liu B, Agron E, Nussenblatt RB, Sen HN. Elevated serum levels of interleukin17A in uveitis patients. Ocul Immunol Inflamm. 2013 Dec;21(6):434-9

36. Li F, Yang P, Liu X, Wang C, Hou S, Kijlstra A. Upregulation of interleukin 21 and promotion of interleukin 17 production in chronic or recurrent Vogt-Koyanagi-Harada disease. Arch Ophthalmol. 2010 Nov;128(11):1449-54

37. Yang P, Foster CS. Interleukin 21, interleukin 23, and transforming growth factor $\beta 1$ in HLA-A29-associated birdshot retinochoroidopathy. Am J Ophthalmol. 2013 Aug;156(2):400-406.e2.

38. Y Peng Y, Han G, Shao H, Wang Y, Kaplan HJ, Sun D. Characterization of IL-17+ interphotoreceptor retinoid-binding protein-specific $\mathrm{T}$ cells in experimental autoimmune uveitis. Invest Ophthalmol Vis Sci. 2007 Sep;48(9):4153-61

39. Grajewski RS, Hansen AM, Agarwal RK, Kronenberg M, Sidobre S, Su SB, Silver PB, Tsuji M, Franck RW, Lawton AP, Chan CC, Caspi RR. Activation of invariant NKT cells ameliorates experimental ocular autoimmunity by a mechanism involving innate IFNgamma production and dampening of the adaptive Th1 and Th17 responses. J Immunol. 2008 Oct 1;181(7):4791-7.

40. Cui Y, Shao H, Lan C, Nian H, O'Brien RL, Born WK, Kaplan HJ, Sun D. Major role of gamma delta T cells in the generation of IL-17+ uveitogenic T cells. J Immunol. 2009 Jul $1 ; 183(1): 560-7$

41. Fossiez F, Banchereau J, Murray R, Van Kooten C, Garrone P, Lebecque S. Interleukin17. Int Rev Immunol. 1998;16(5-6):541-51

42. van Kooij B, Rothova A, Rijkers GT, de Groot-Mijnes JD. Distinct cytokine and chemokine profiles in the aqueous of patients with uveitis and cystoid macular edema. Am J Ophthalmol. 2006 Jul;142(1):192-4

43. O'Garra A, Vieira PL, Vieira P, Goldfeld AE. IL-10-producing and naturally occurring CD4+ Tregs: limiting collateral damage. J Clin Invest. 2004 Nov;114(10):1372-8.

44. Asadullah K, Sterry W, Volk HD. Interleukin-10 therapy--review of a new approach. Pharmacol Rev. 2003 Jun;55(2):241-69 
bioRxiv preprint doi: https://doi.org/10.1101/2021.08.04.455093; this version posted August 4, 2021. The copyright holder for this preprint (which was not certified by peer review) is the author/funder, who has granted bioRxiv a license to display the preprint in perpetuity. It is made available under aCC-BY 4.0 International license.

Immune mediators in idiopathic uveitis

45. Ongkosuwito JV, Feron EJ, van Doornik CE, Van der Lelij A, Hoyng CB, La Heij EC, Kijlstra A. Analysis of immunoregulatory cytokines in ocular fluid samples from patients with uveitis. Invest Ophthalmol Vis Sci. 1998 Dec;39(13):2659-65

46. Dardalhon V, Korn T, Kuchroo VK, Anderson AC. Role of Th1 and Th17 cells in organspecific autoimmunity. J Autoimmun. 2008 Nov;31(3):252-6

47. Veldhoen M, Hocking RJ, Atkins CJ, Locksley RM, Stockinger B. TGFbeta in the context of an inflammatory cytokine milieu supports de novo differentiation of IL-17-producing T cells. Immunity. 2006 Feb;24(2):179-89

48. Kundu-Raychaudhuri S, Abria C, Raychaudhuri SP. IL-9, a local growth factor for synovial T cells in inflammatory arthritis. Cytokine. 2016 Mar;79:45-51

49. Ruocco G, Rossi S, Motta C, Macchiarulo G, Barbieri F, De Bardi M, Borsellino G, Finardi A, Grasso MG, Ruggieri S, Gasperini C, Furlan R, Centonze D, Battistini L, Volpe E. $\mathrm{T}$ helper 9 cells induced by plasmacytoid dendritic cells regulate interleukin-17 in multiple sclerosis. Clin Sci (Lond). 2015 Aug;129(4):291-303

50. Ciccia F, Guggino G, Ferrante A, Cipriani P, Giacomelli R, Triolo G. Interleukin-9 and T helper type 9 cells in rheumatic diseases. Clin Exp Immunol. 2016 Aug; 185(2):125-32 51. Klok AM, Luyendijk L, Zaal MJ, Rothova A, Hack CE, Kijlstra A. Elevated serum IL-8 levels are associated with disease activity in idiopathic intermediate uveitis. Br J Ophthalmol. 1998 Aug;82(8):871-4

52. Gür-Toy G, Lenk N, Yalcin B, Aksaray S, Alli N. Serum interleukin-8 as a serologic marker of activity in Behçet's disease. Int J Dermatol. 2005 Aug;44(8):657-60

53. Sahin S, Akoğlu T, Direskeneli H, Sen LS, Lawrence R. Neutrophil adhesion to endothelial cells and factors affecting adhesion in patients with Behçet's disease. Ann Rheum Dis. 1996 Feb;55(2): 128-33

54. Chen P, Denniston A, Hannes S, Tucker W, Wei L, Liu B, Xiao T, Hirani S, Li Z, Jawad $\mathrm{S}$, Si H, Lee RW, Sen HN, Nussenblatt RB. Increased CD1c+ mDC1 with mature phenotype regulated by TNF $\alpha$-p38 MAPK in autoimmune ocular inflammatory disease. Clin Immunol. 2015 May;158(1):35-46

55. Yoshimura T, Sonoda KH, Ohguro N, Ohsugi Y, Ishibashi T, Cua DJ, Kobayashi T, Yoshida H, Yoshimura A. Involvement of Th17 cells and the effect of anti-IL-6 therapy in autoimmune uveitis. Rheumatology (Oxford). 2009 Apr;48(4):347-54

56. Mesquida M, Leszczynska A, Llorenç V, Adán A. Interleukin-6 blockade in ocular inflammatory diseases. Clin Exp Immunol. 2014 Jun;176(3):301-9

57. Li X, Stark GR. NFkappaB-dependent signaling pathways. Exp Hematol. 2002 Apr;30(4):285-96

58. Perez VL, Papaliodis GN, Chu D, Anzaar F, Christen W, Foster CS. Elevated levels of interleukin 6 in the vitreous fluid of patients with pars planitis and posterior uveitis: the Massachusetts eye \& ear experience and review of previous studies. Ocul Immunol Inflamm. 2004 Sep;12(3):193-201

59. Nakamura H, Ueki Y, Sakito S, Matsumoto K, Yano M, Miyake S, Tominaga T, Tominaga M, Eguchi K. High serum and synovial fluid granulocyte colony stimulating factor (G-CSF) concentrations in patients with rheumatoid arthritis. Clin Exp Rheumatol. 2000 Nov-Dec;18(6):713-8

60. Pillinger $\mathrm{MH}$, Abramson SB. The neutrophil in rheumatoid arthritis. Rheum Dis Clin North Am. 1995 Aug;21(3):691-714

61. Yuo A, Kitagawa S, Ohsaka A, Ohta M, Miyazono K, Okabe T, Urabe A, Saito M, Takaku F. Recombinant human granulocyte colony-stimulating factor as an activator of human granulocytes: potentiation of responses triggered by receptor-mediated agonists and stimulation of C3bi receptor expression and adherence. Blood. 1989 Nov 1;74(6):2144-9 
62. Ajuebor MN, Gibbs L, Flower RJ, Das AM, Perretti M. Investigation of the functional role played by the chemokine monocyte chemoattractant protein-1 in interleukin-1-induced murine peritonitis. Br J Pharmacol. 1998 Sep;125(2):319-26

63. Franks WA, Limb GA, Stanford MR, Ogilvie J, Wolstencroft RA, Chignell AH, Dumonde 
(which was not certified by peer review) is the author/funder, who has granted bioRxiv a license to display the preprint in perpetuity. It is

IP-10 serum

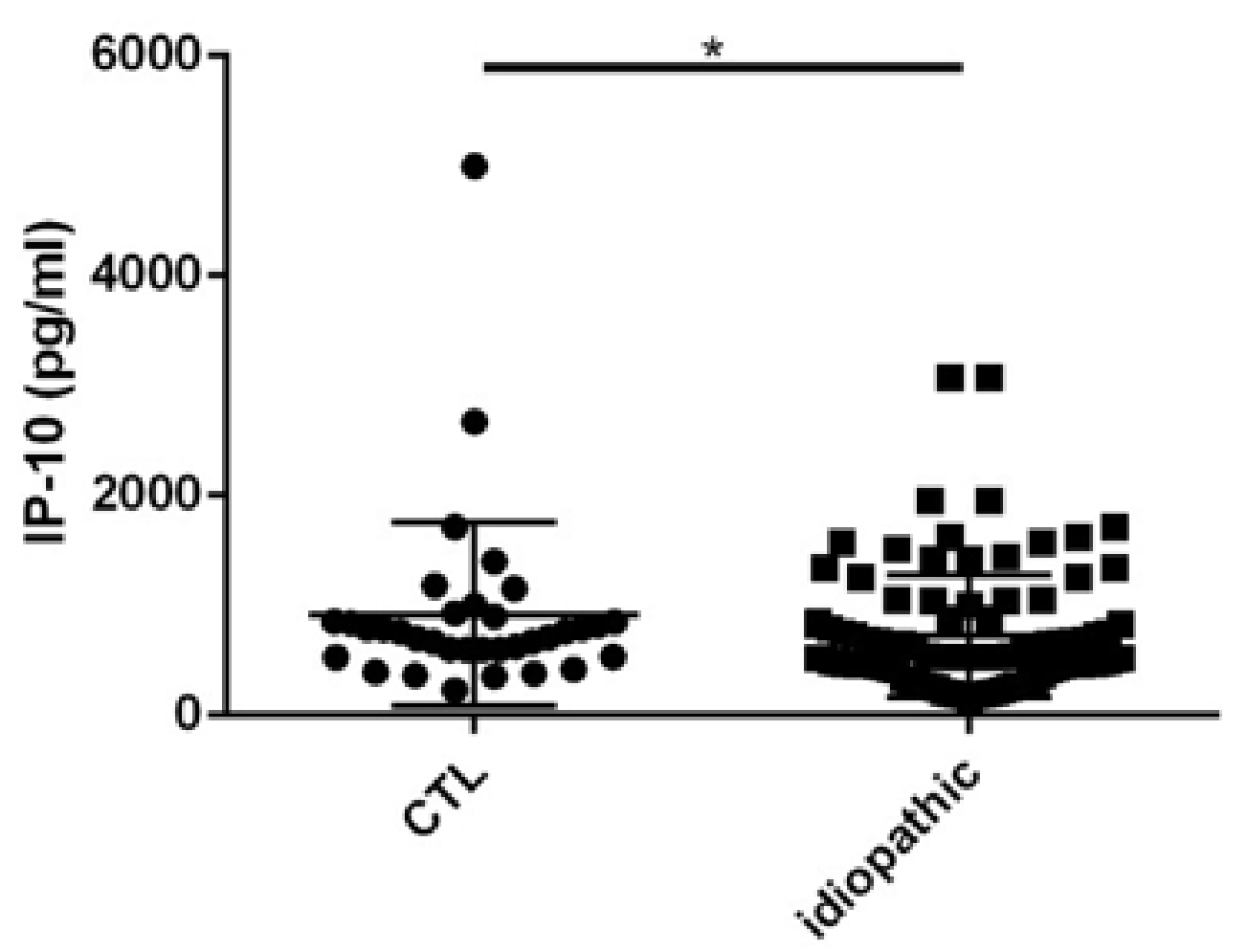

IL-17 serum

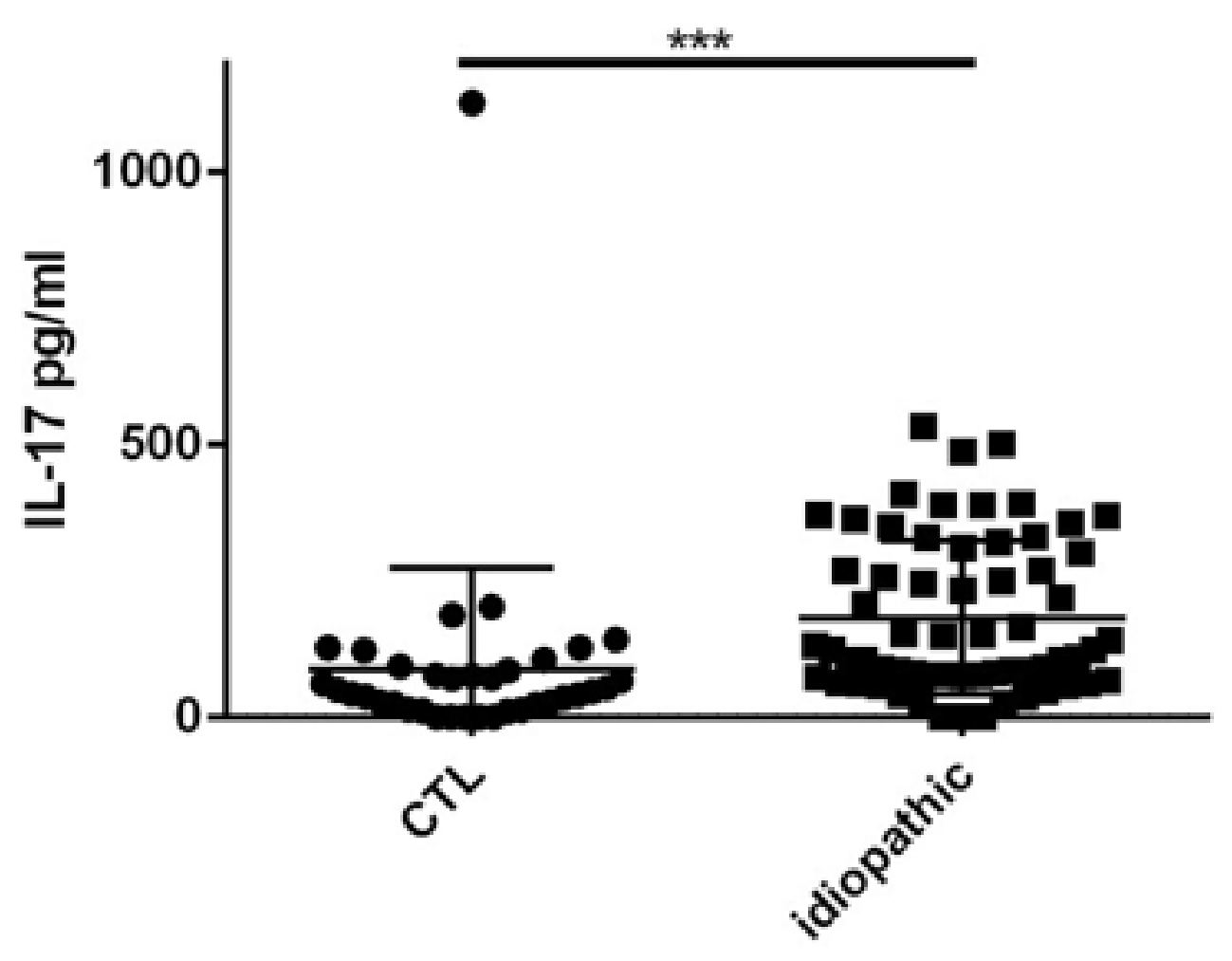

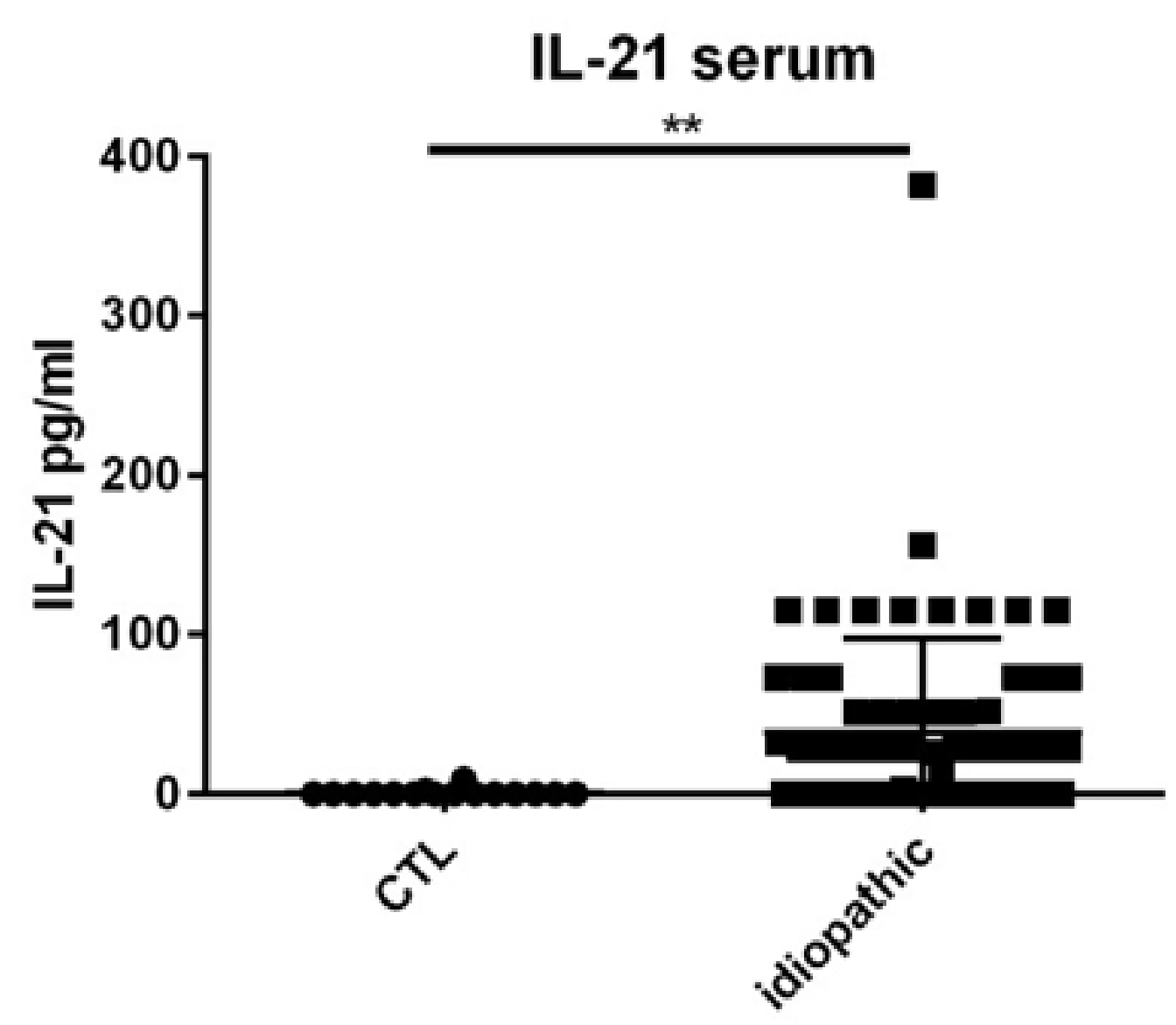

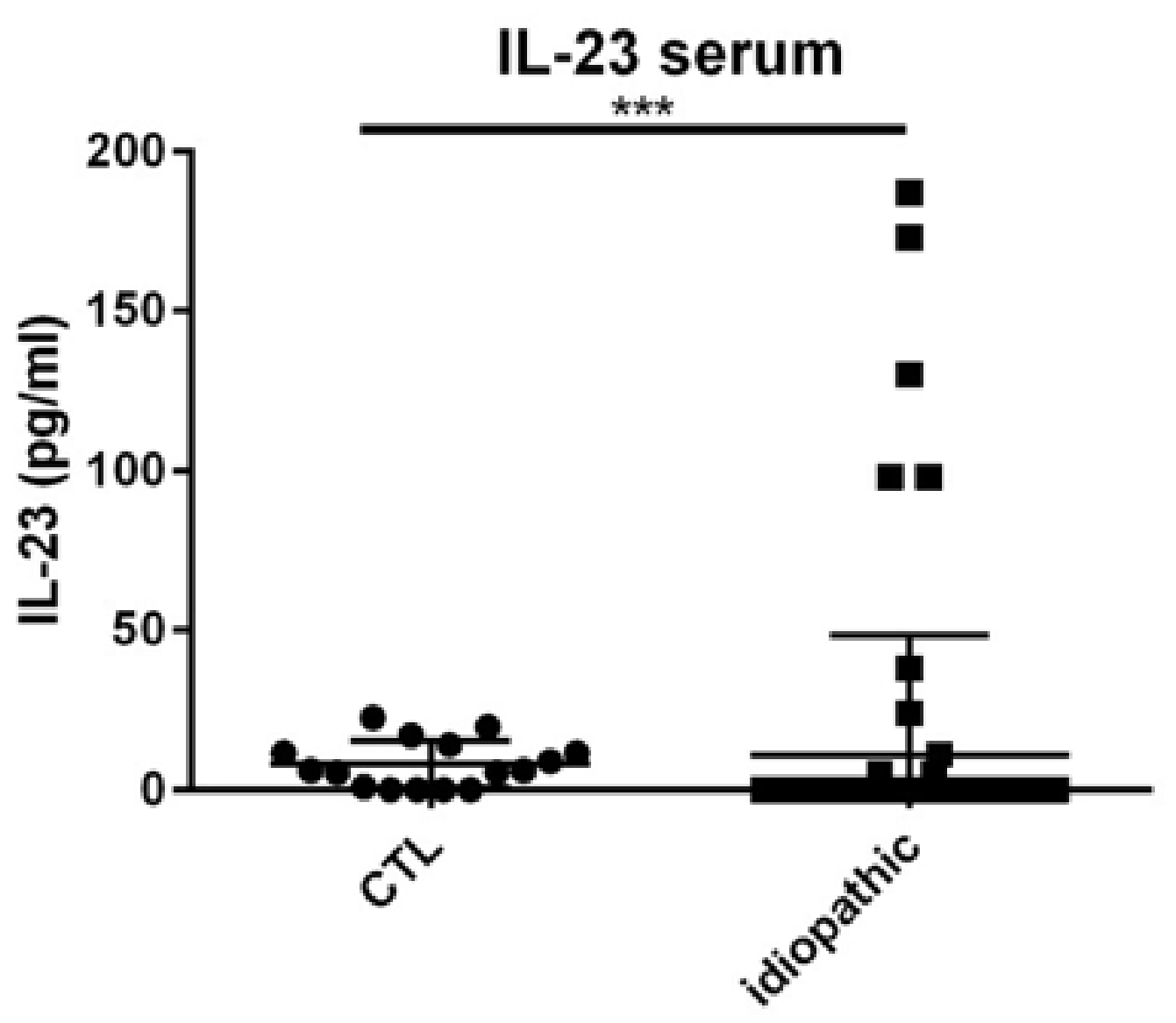

Figure 
IL-1b serum

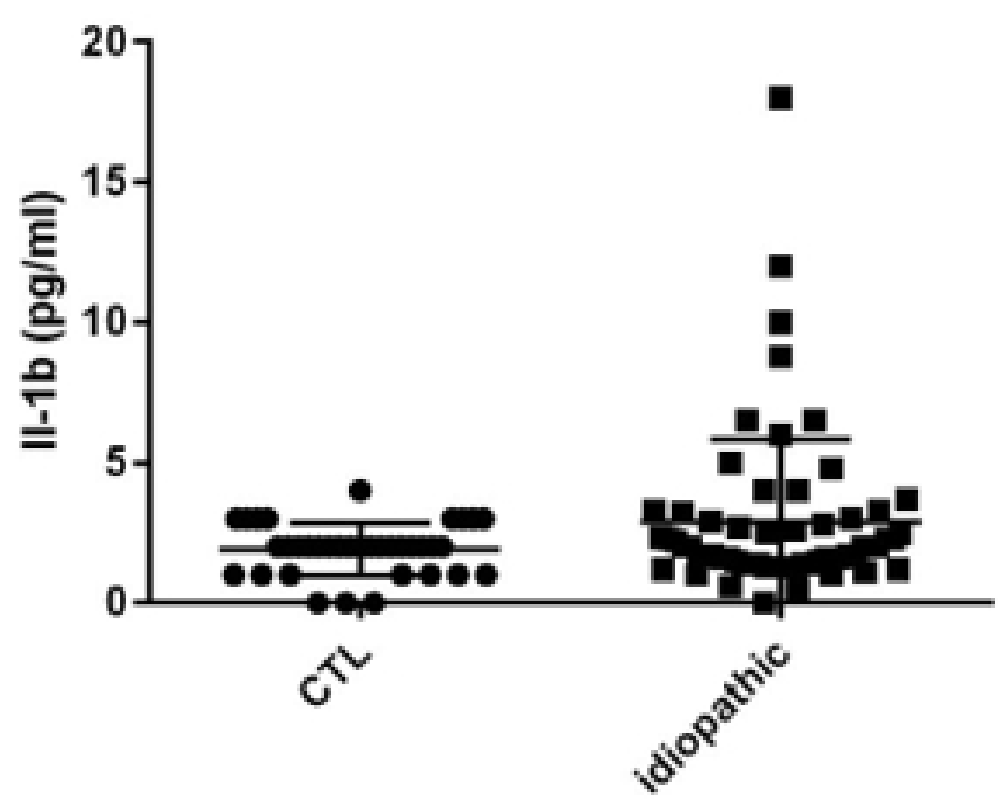

IFN-g serum

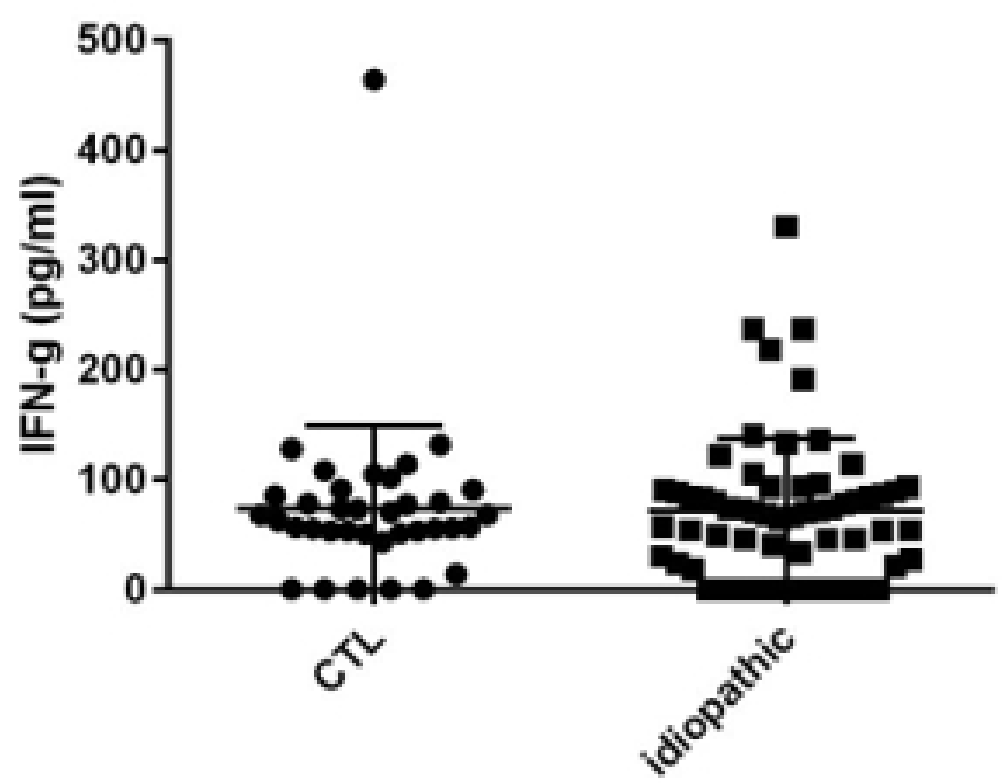

IL-6 serum

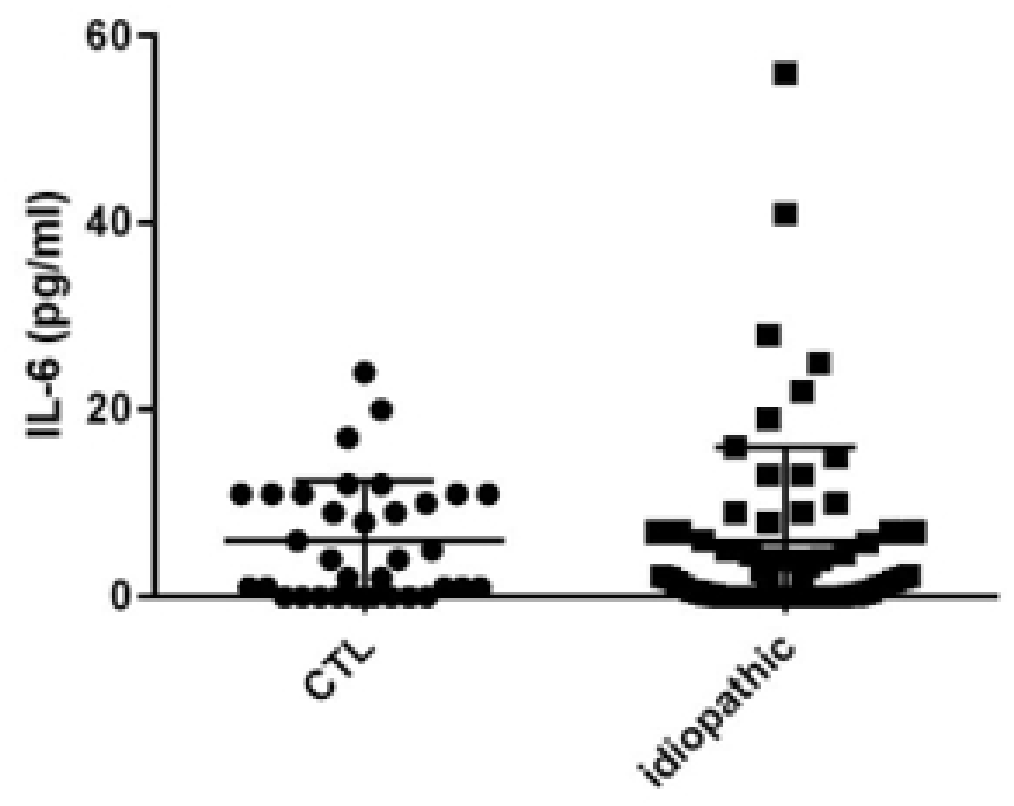

TNF-a serum

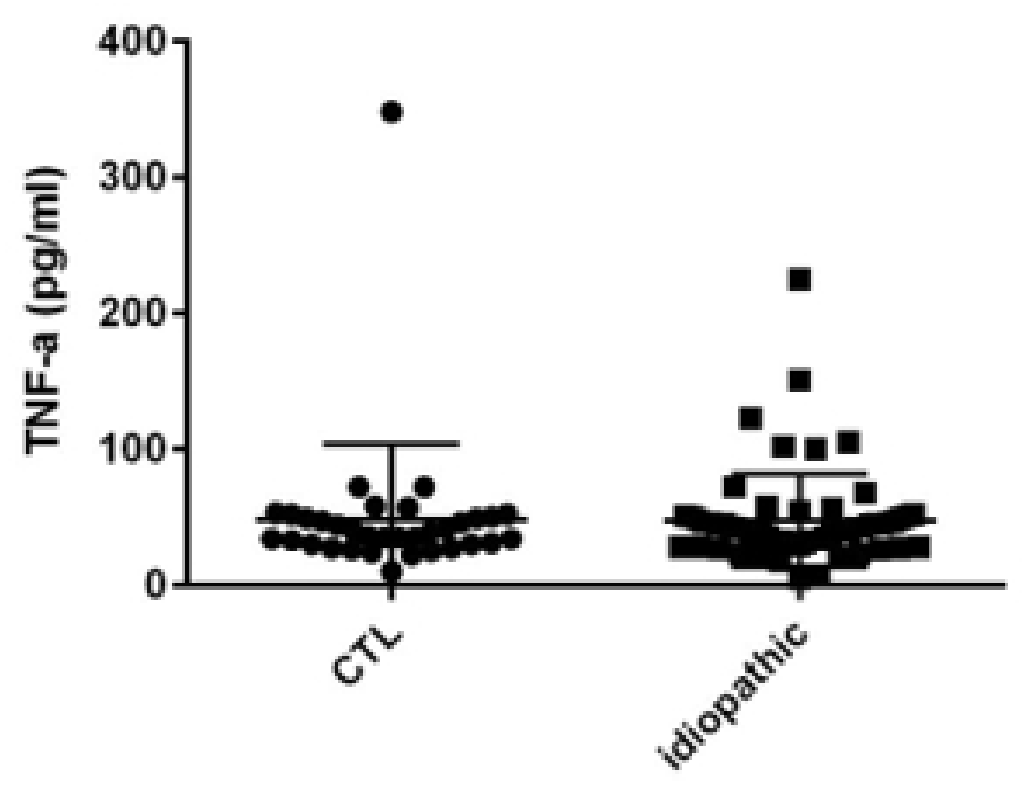

Figure 2 

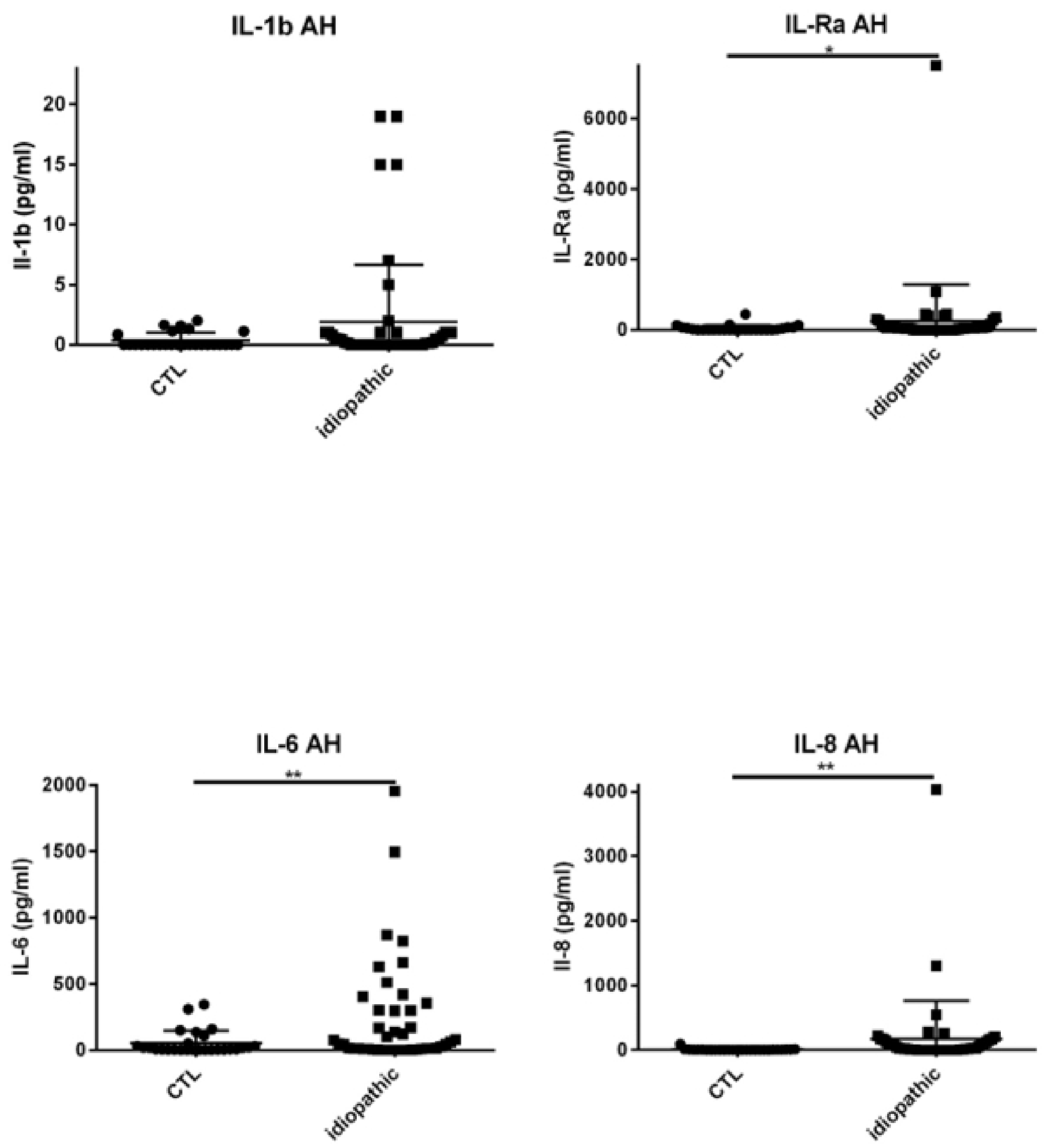

Figure 3a 
IL-10 AH
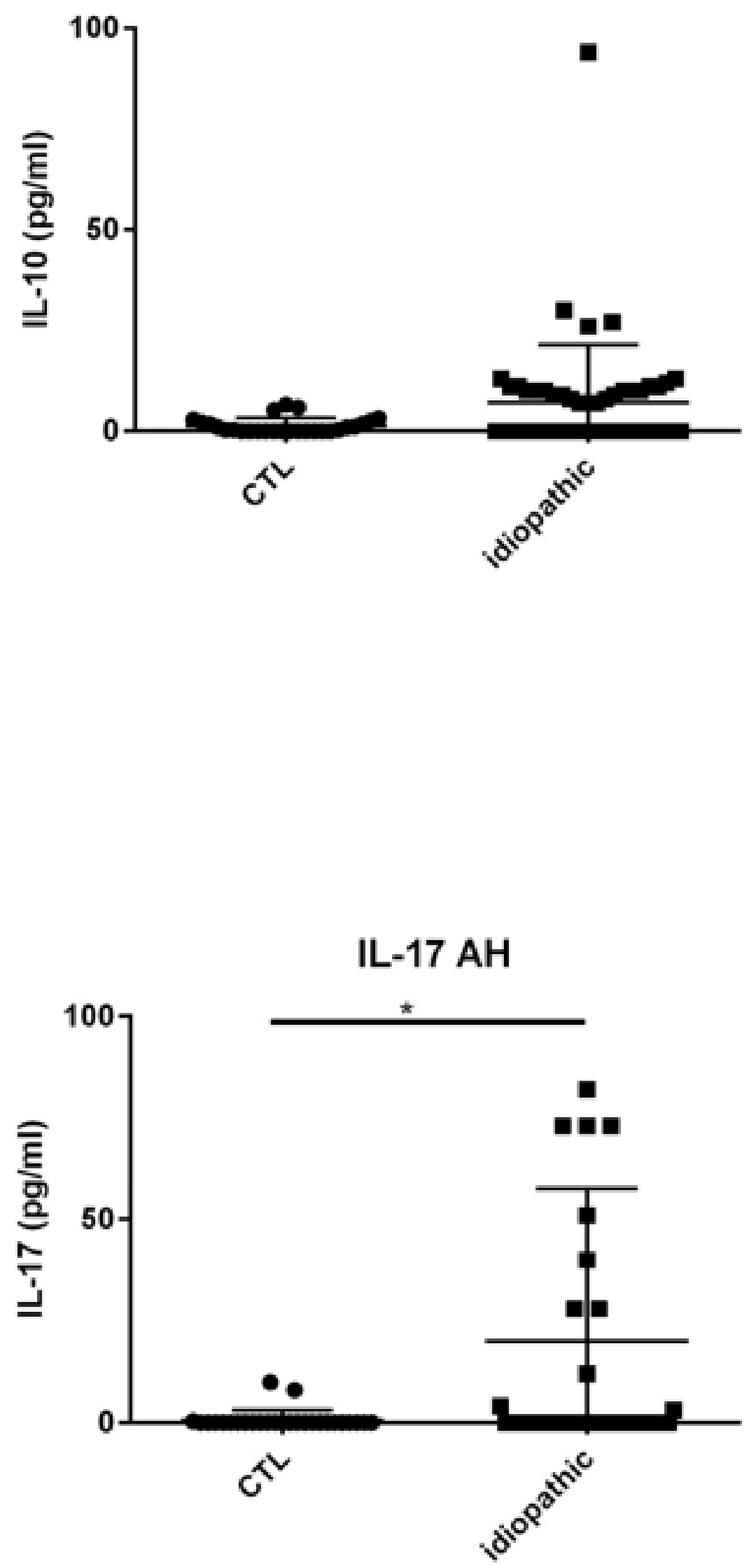

IL-12 AH
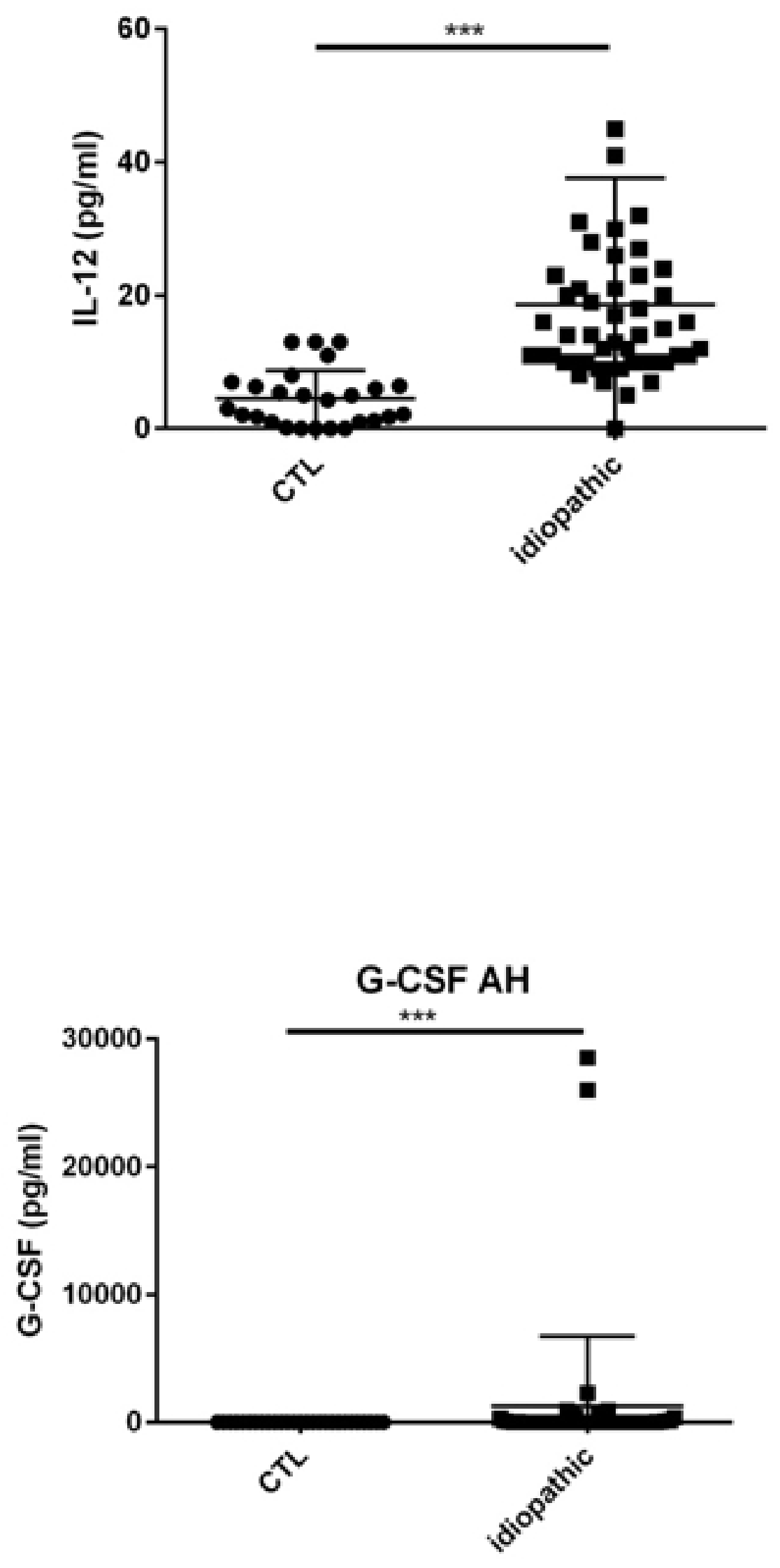

Figure 3b 
IFN-g AH
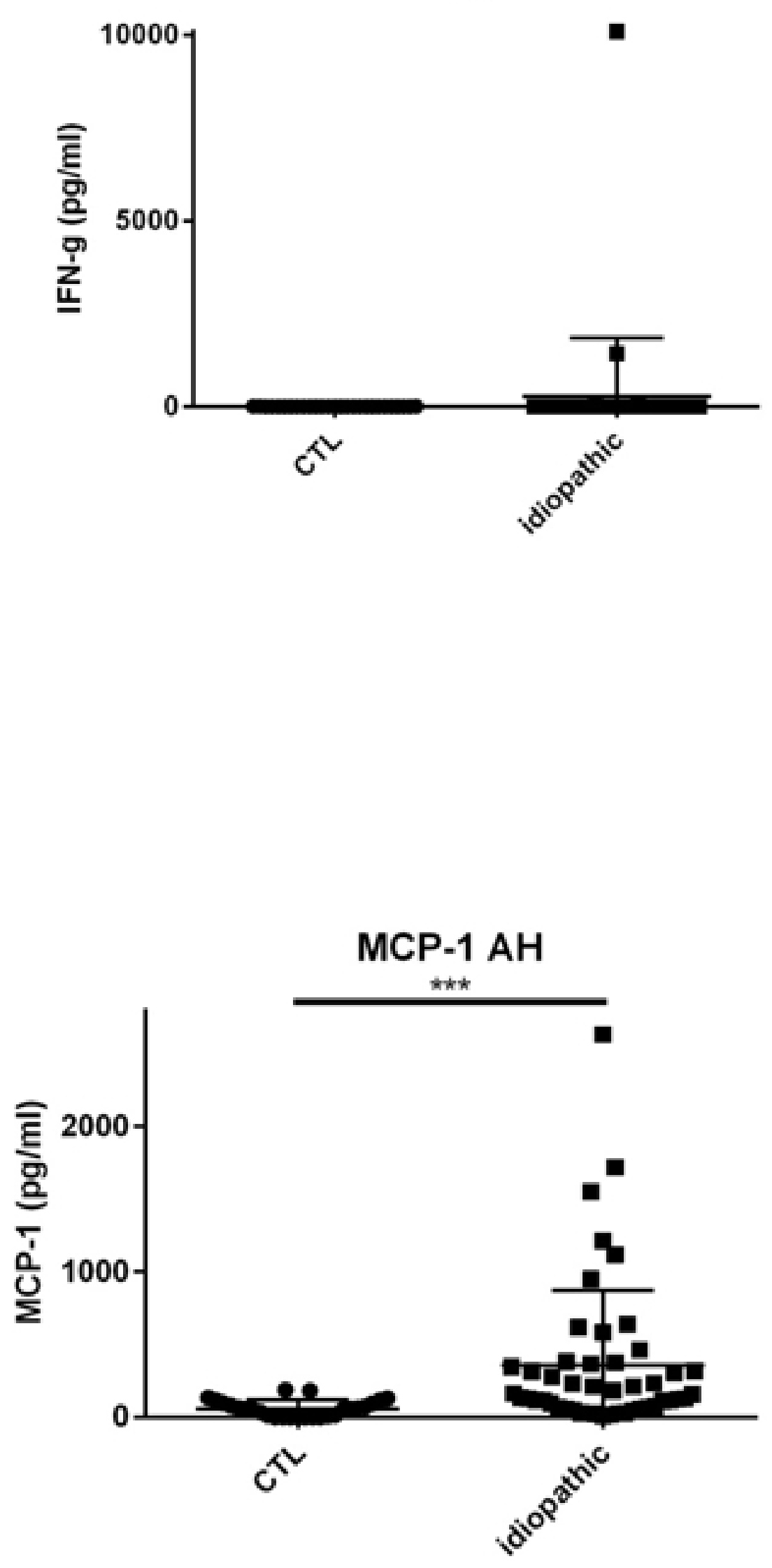

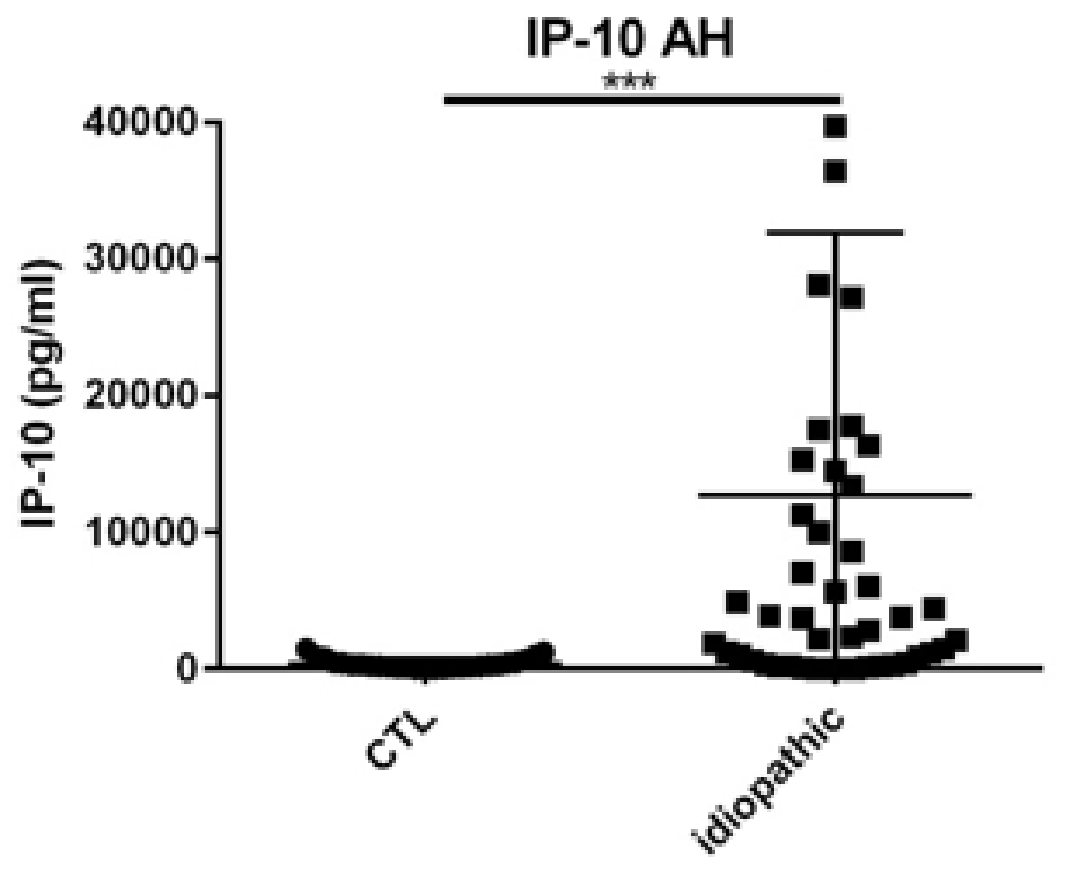

MIP-1a AH

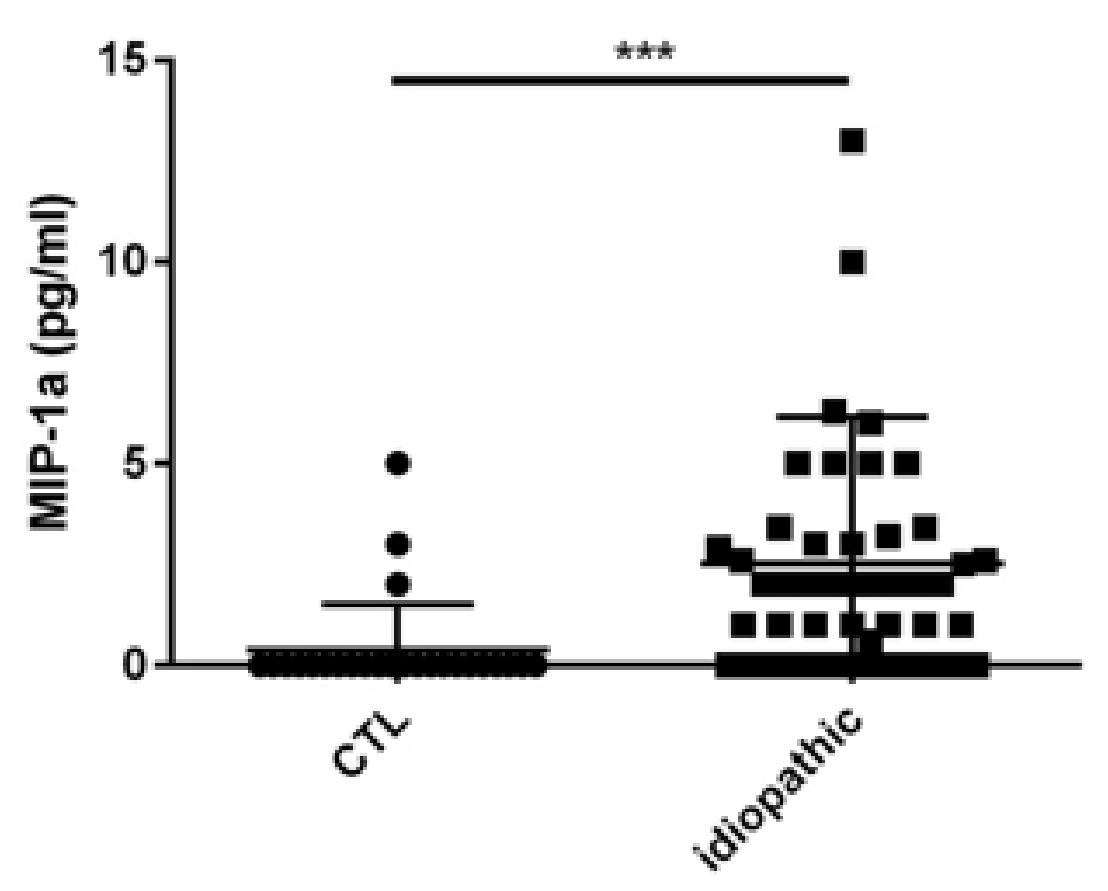

Figure $3 c$ 


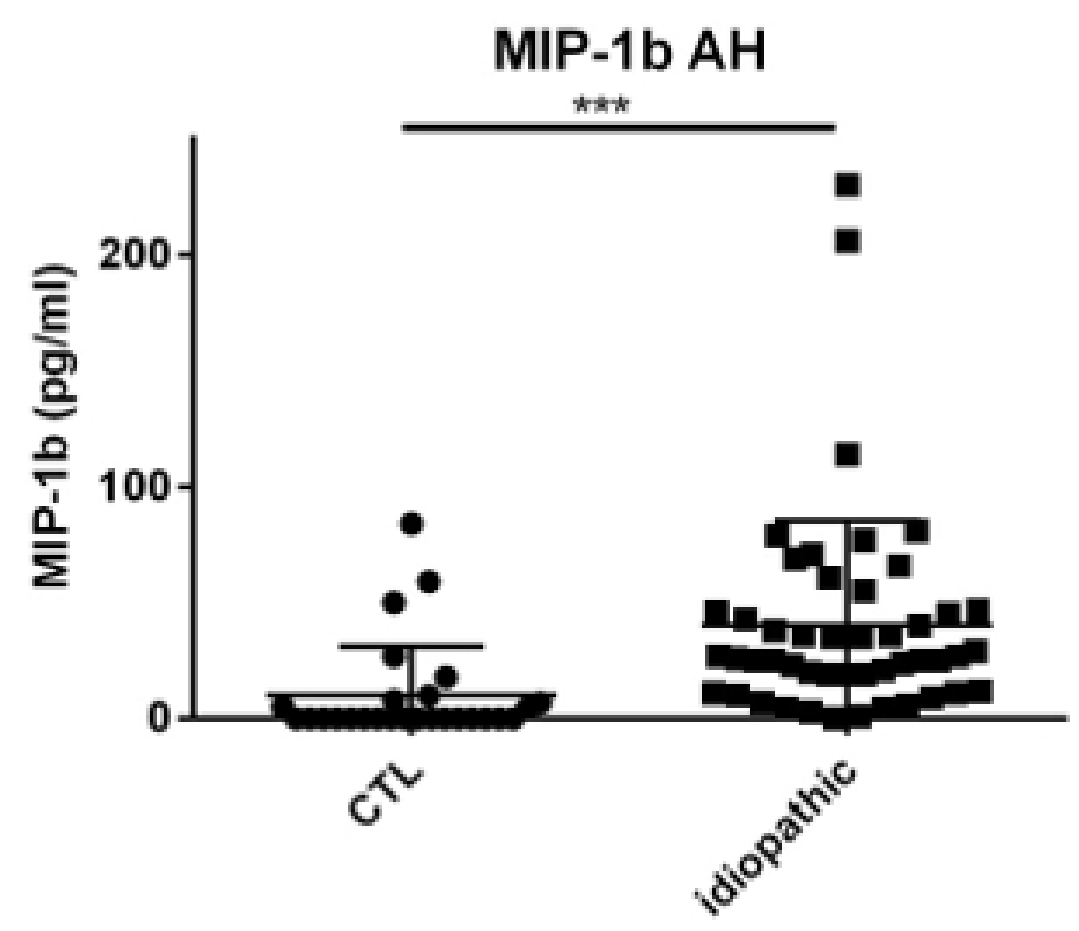

RANTES AH

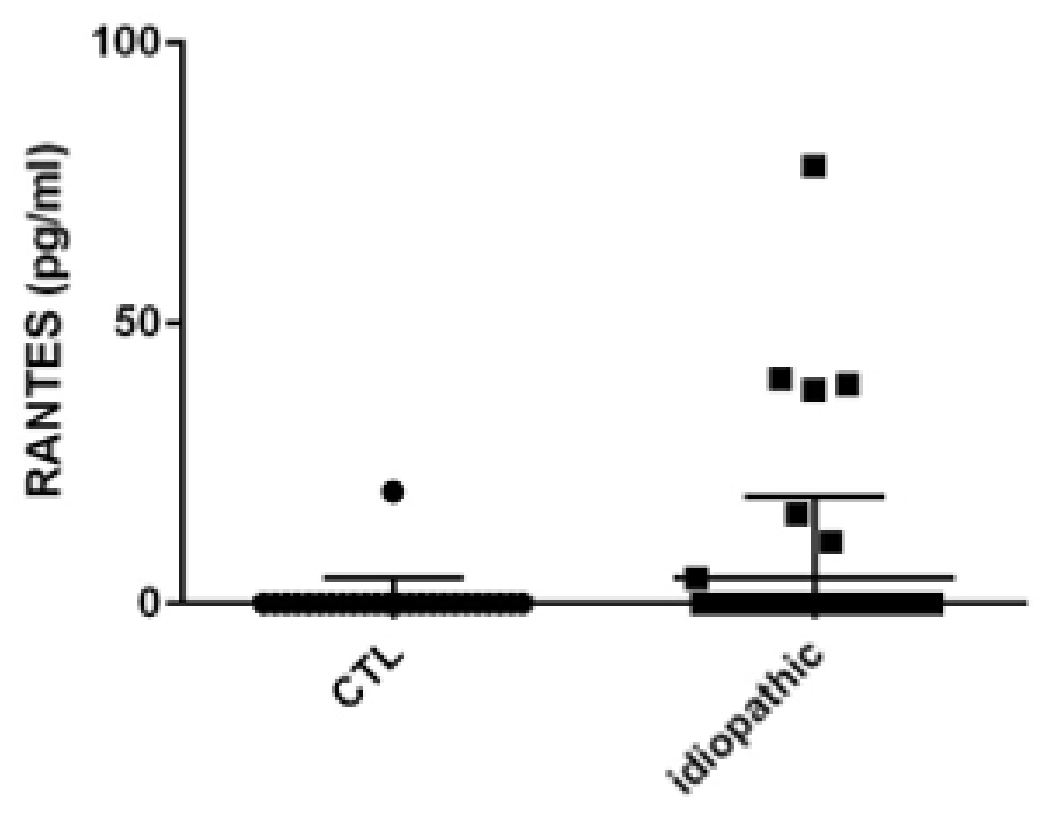

TNF-a AH

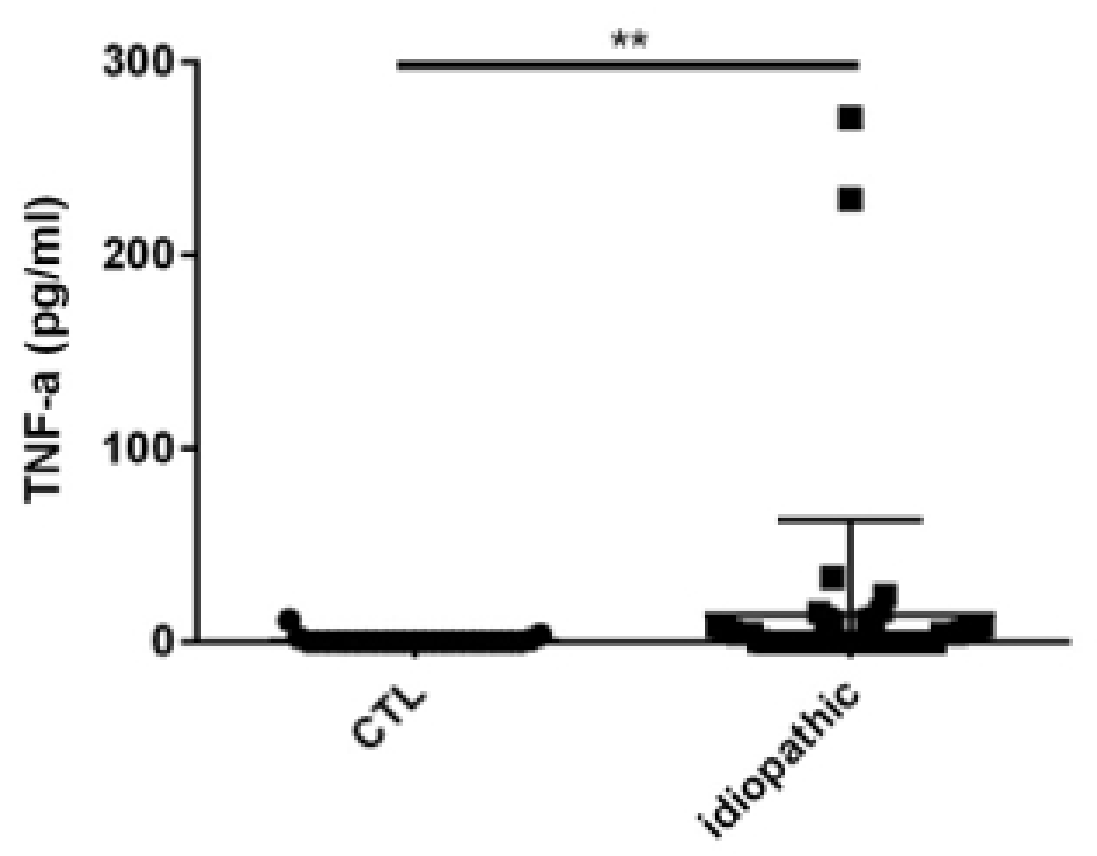

Figure 3d 


\section{VEGF AH}

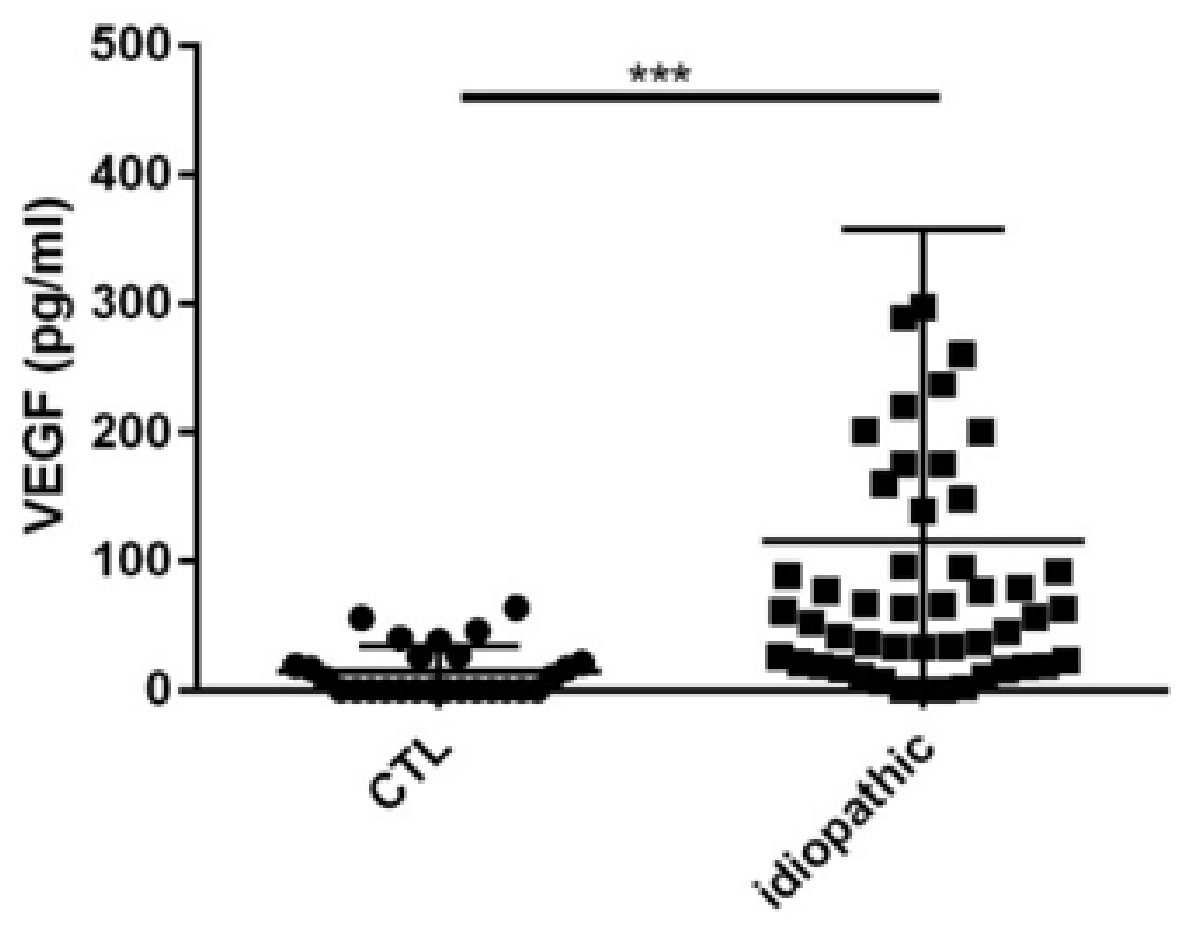

PDFG-BB HA

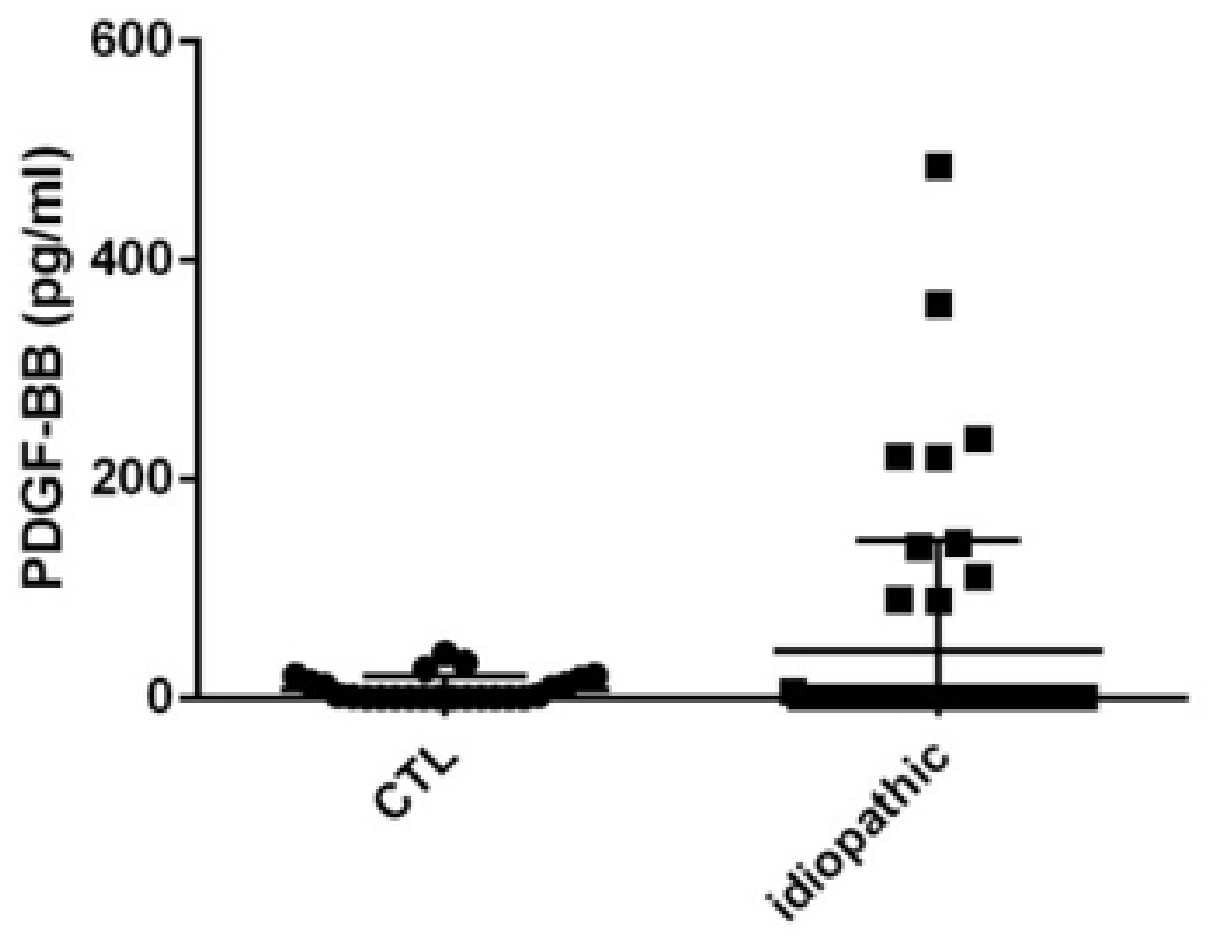

Figure 3e 


\section{IL-6}

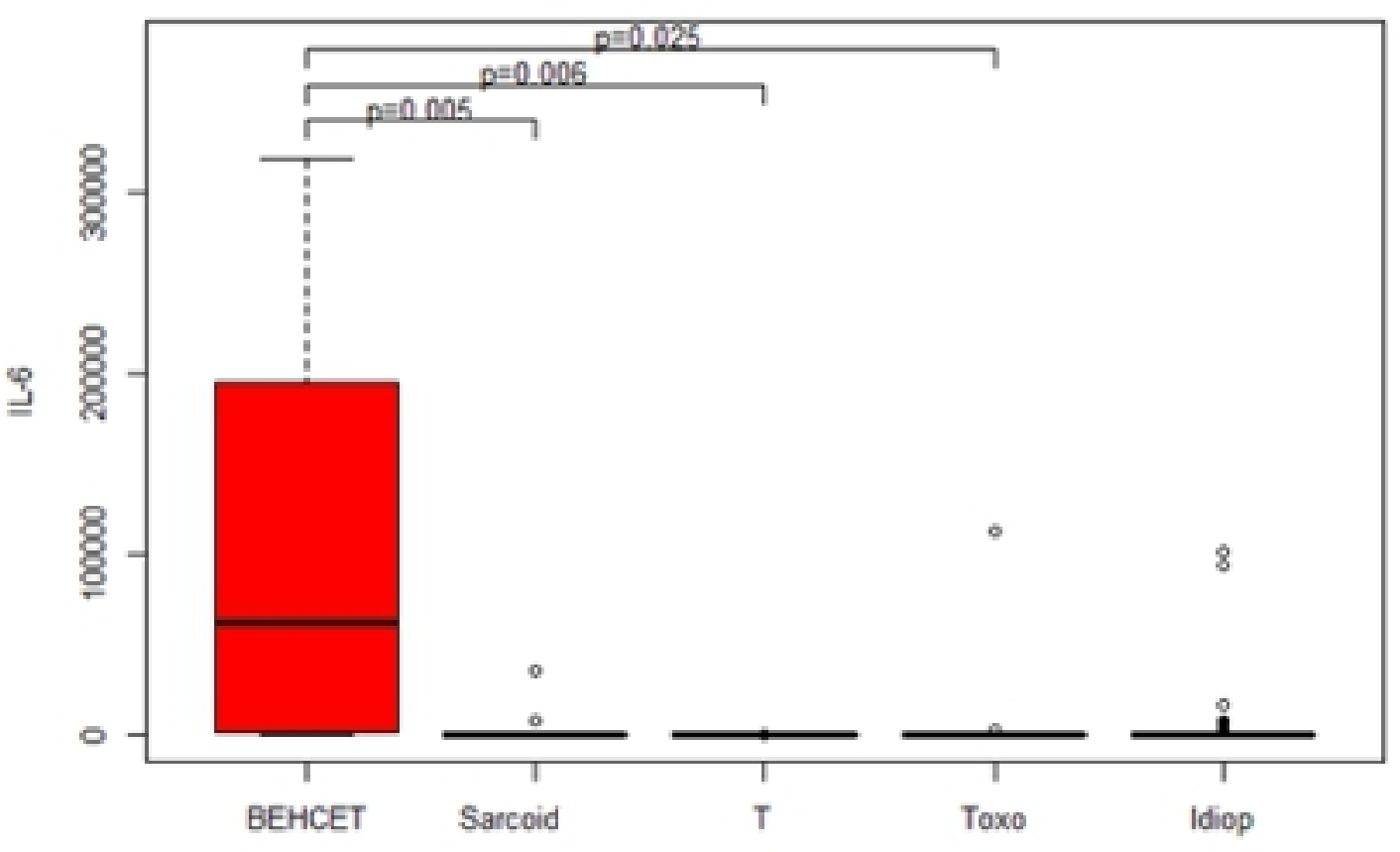

IP-10

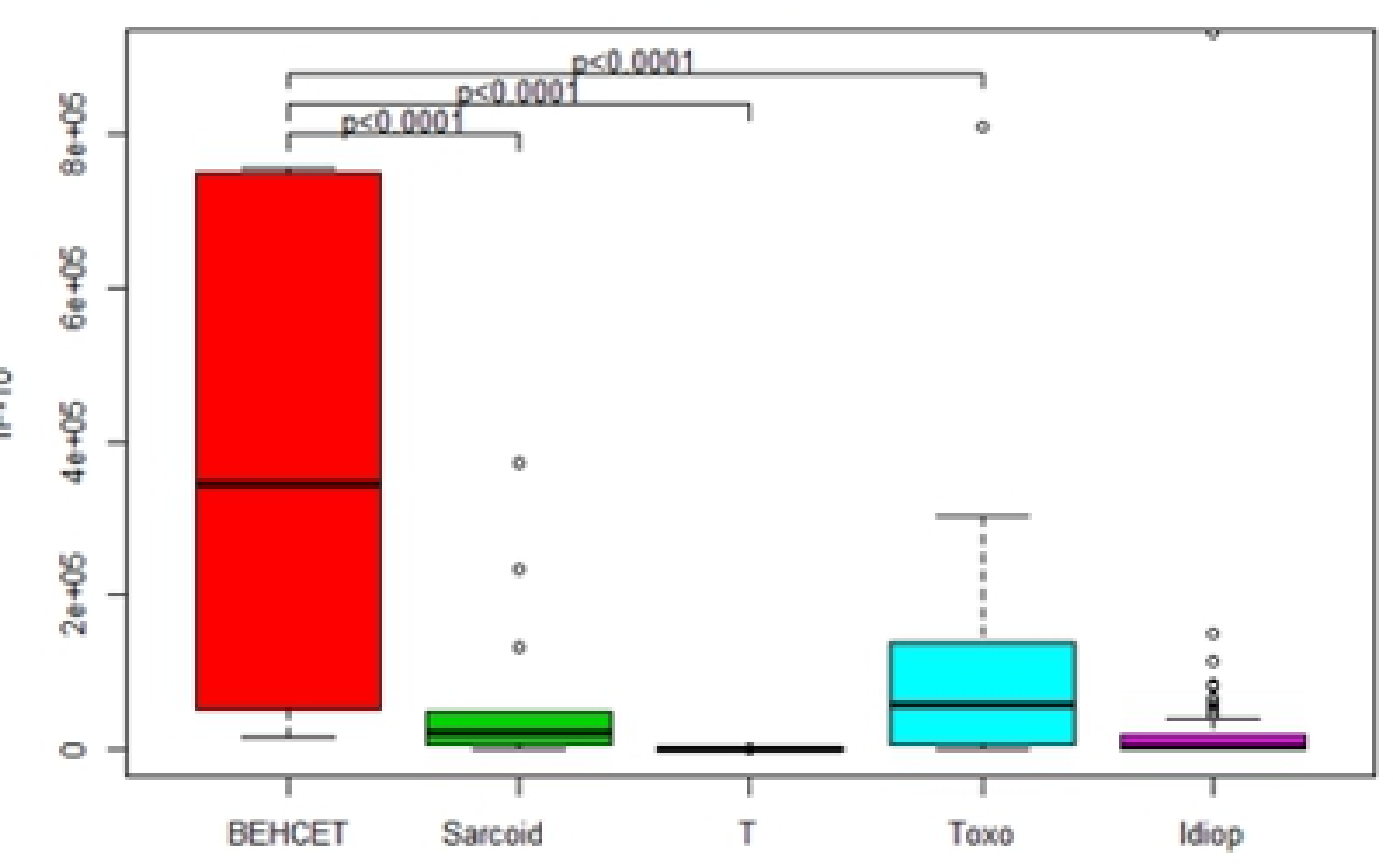

TNF-a

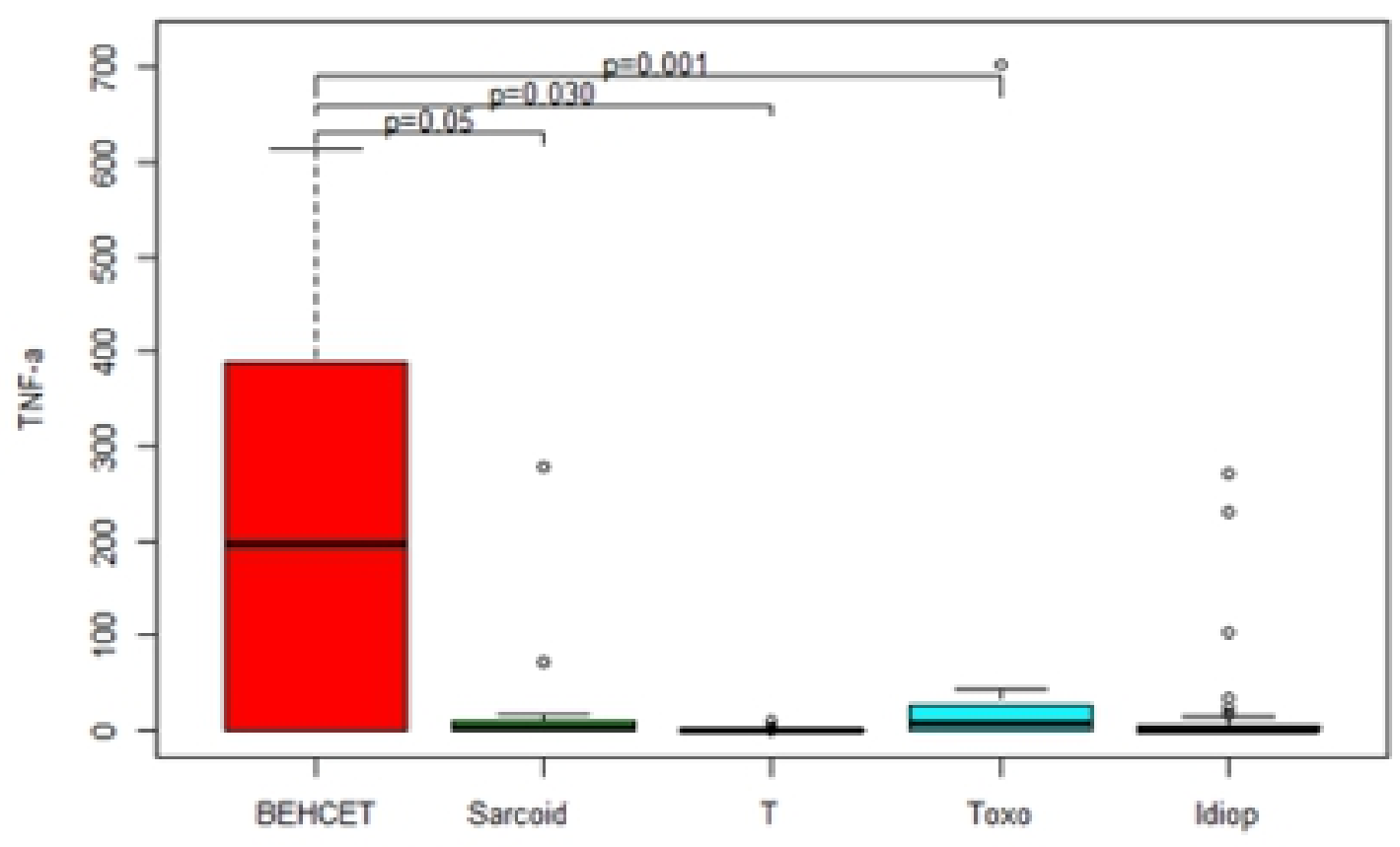

IL-12

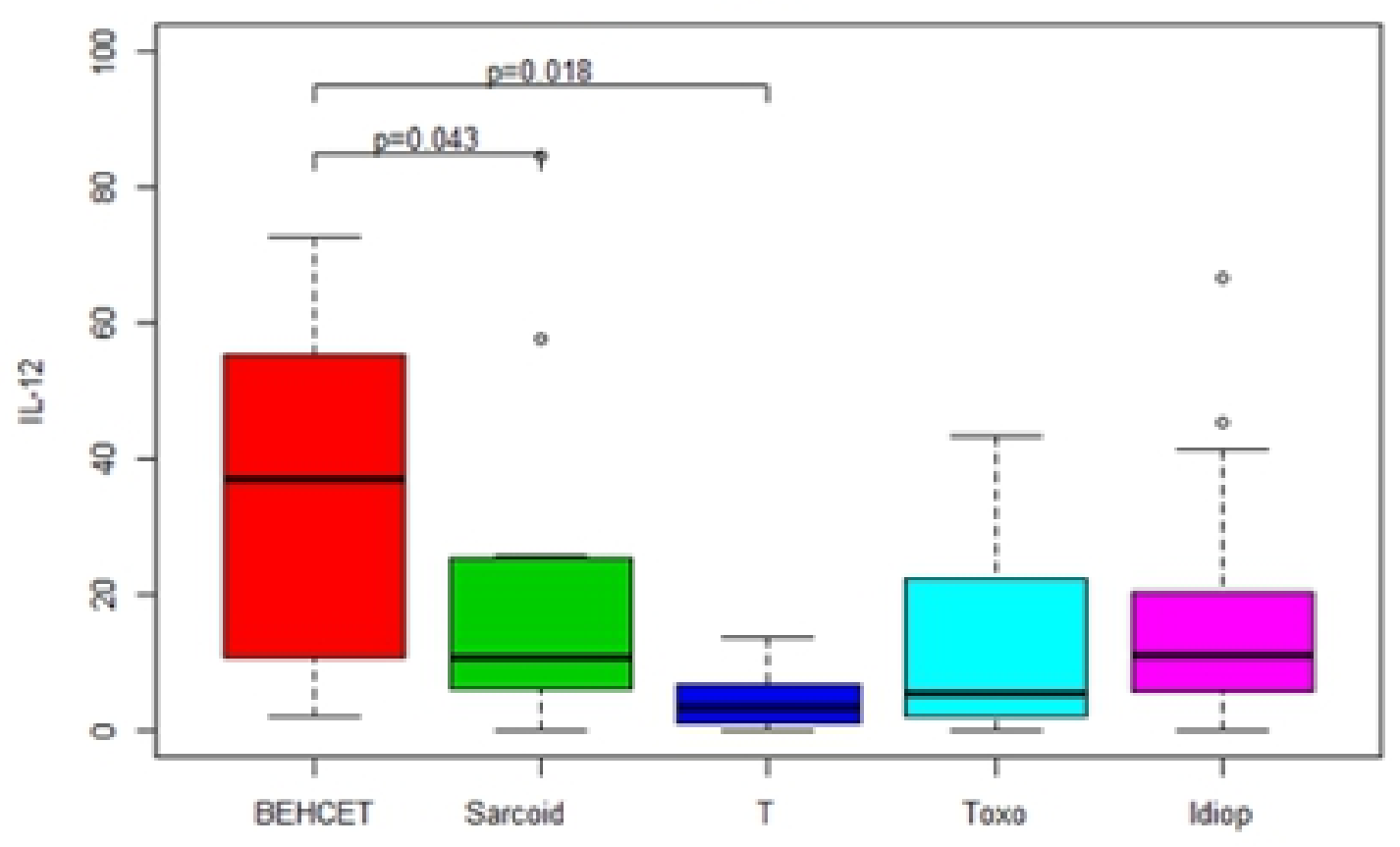

Figure 5 

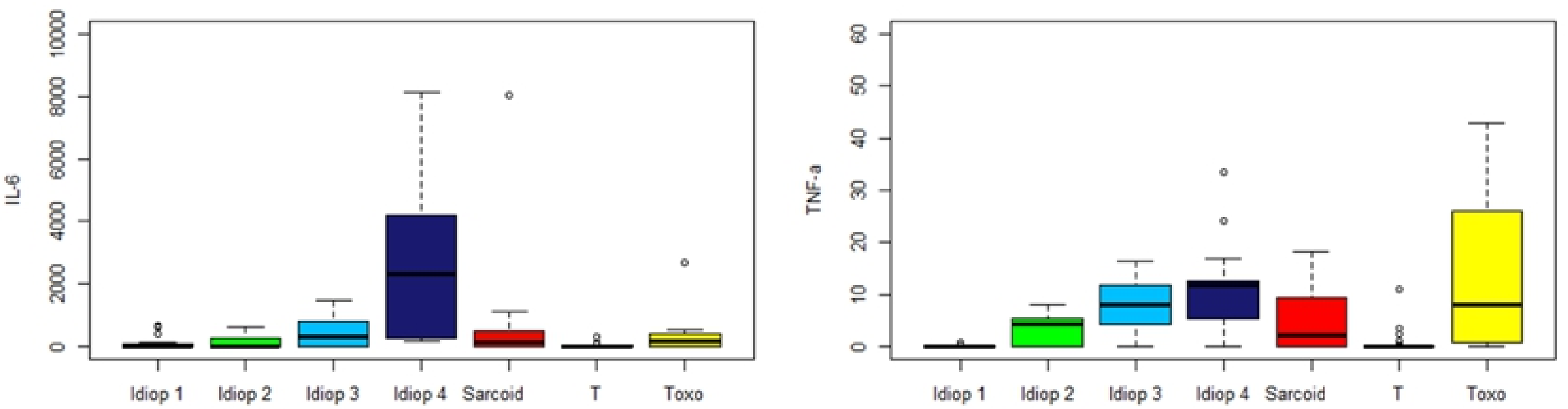

IP-10
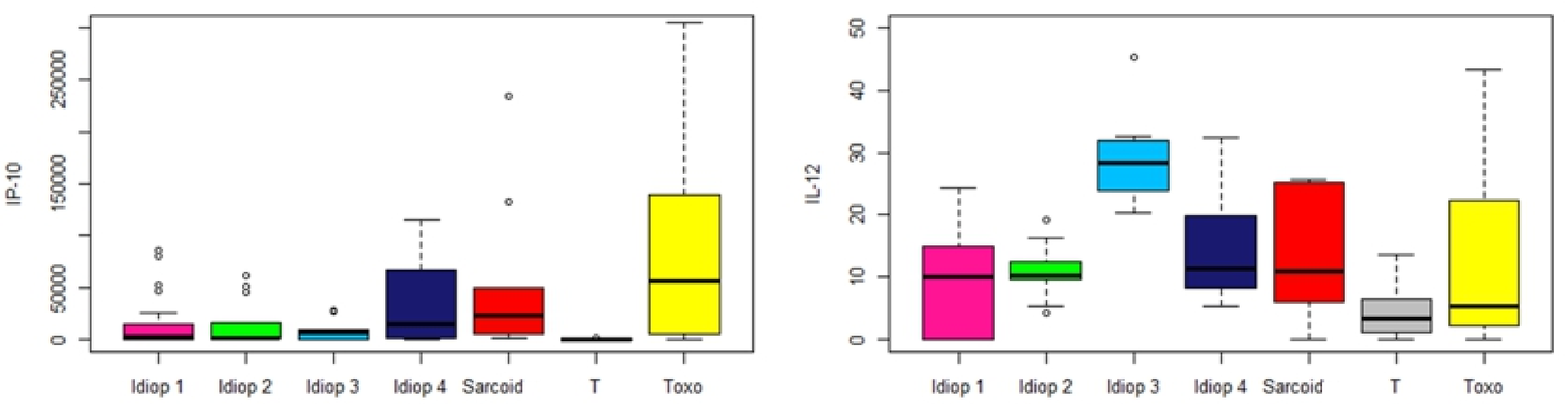

Figure 6 